NBER WORKING PAPER SERIES

\title{
DOES GENDER MATTER FOR PROMOTION IN SCIENCE? EVIDENCE FROM PHYSICISTS IN FRANCE
}

\author{
Jacques Mairesse \\ Michele Pezzoni \\ Fabiana Visentin \\ Working Paper 27789 \\ http://www.nber.org/papers/w27789 \\ NATIONAL BUREAU OF ECONOMIC RESEARCH \\ 1050 Massachusetts Avenue \\ Cambridge, MA 02138
}

September 2020

We are indebted to Alain Schuhl and Anne Sigogneau for their great help in implementing our online survey on family and research responsibilities of the INP physicists, and to Thierry Kamionka, Jackie Krafft and Nathalie Lazaric for advice and comments. The views expressed herein are those of the authors and do not necessarily reflect the views of the National Bureau of Economic Research.

NBER working papers are circulated for discussion and comment purposes. They have not been peer-reviewed or been subject to the review by the NBER Board of Directors that accompanies official NBER publications.

(C) 2020 by Jacques Mairesse, Michele Pezzoni, and Fabiana Visentin. All rights reserved. Short sections of text, not to exceed two paragraphs, may be quoted without explicit permission provided that full credit, including (C) notice, is given to the source. 
Does Gender Matter for Promotion in Science? Evidence from Physicists in France Jacques Mairesse, Michele Pezzoni, and Fabiana Visentin

NBER Working Paper No. 27789

September 2020

JEL No. I23,J16

\begin{abstract}
$\underline{\text { ABSTRACT }}$ responsibilities have different impacts on female and male researchers.

Jacques Mairesse

CREST (ParisTech-ENSAE)

5, Avenue Henri Le Chatelier

91120 PALAISEAU

FRANCE

and UNU-MERIT (Maastricht University)

and also NBER

mairesse@ensae.fr

Michele Pezzoni

University Côte d'Azur

GREDEG

250 rue Albert Einstein CS 10269

06905 Sophia Antipolis Cedex

France

and GREDEG

michele.pezzoni@unice.fr

Fabiana Visentin

UNU-MERIT

Boschstraat 24

6211 AX Maastricht

Netherlands

visentin@merit.unu.edu
\end{abstract}

In this study, we investigate what are the factors of the promotion of female and male scientists at the French Institute of Physics (INP) at CNRS, one of the largest European public research organizations. We construct a long panel of INP physicists combining various data sources on their research activities and career. Using event history analysis, we find that female and male physicists have the same rate of promotion from junior to senior positions when controlling for research productivity and a variety of other promotion factors. Our results also suggest that promotion factors such as family characteristics, mentoring, professional network, research 


\section{Introduction}

In this study, we investigate what are the factors of promotion of female and male scientists, trying to understand whether and why "many women are deterred from pursuing a career in science at the highest level," as claimed in a Nature’s editorial (Nature Editorial [2013]). We consider one of the largest European public research organizations, the French National Center for Scientific Research (CNRS). CNRS is an ideal setting for studying gender disparity in the promotion since researchers are ranked on a promotion scale, based on criteria well-defined and publicly available.

Our study is conducted on a panel data sample of researchers working at the Institute of Physics (INP), the Institute of CNRS specialized in the field of physics. For the institute, we were able to combine administrative and bibliometric data, as well as specific information gathered from an online survey. Based on these data and relying on event history analysis, we analyze promotions from the entry positions or ranks of junior researcher to the highest ones of senior researcher: in French at CNRS from 'Chargé de Recherche' to 'Directeur de Recherche,' we shall denote (CR) and (DR).

In this setting, we present our analysis and its results in two steps. In the first step, we follow the mainstream literature by investigating whether factors of promotion, direct and indirect, such as research productivity and family characteristics, can account for differences in the promotion rates of the female and male physicists of INP from CR to DR ranks. In addition to the usual measure of research output, i.e., the number of publications and citations received, we also consider complementary research activities such as mentoring, professional networking, fundraising, technology transfer, and project management activities (as in Leahey [2007]; Weisshaar [2017], Pezzoni et al. [2016]). We have also considered family characteristics as in Fox [2001], Ginther and Hayes [1999], and Long, Allison, and McGinnis [1993]. Those family 
characteristics information has been retrieved in an online survey in which the authors inquiry the INP researchers about the number and age of thir children (see Pezzoni, Mairesse and Visentin [2019] for detailed information about the online survey). Controlling for all these factors, we find that female and male physicists have the same rate of promotion from CR to DR ranks.

In the second step of our analysis, we focus explicitly on assessing whether the variety of factors of promotion investigated in the first step related to research output, complementary activities, and family characteristics, counts differently for women and men. In particular, we find that quantity and quality of scientific publications, and being head of a research team is equally beneficial for the promotion of female and male physicists. Having a larger number of children is beneficial for the promotion of male researchers, not female, and having less than three years old child does not significantly affect the promotion of neither of them.

Our study contributes to the empirical literature about promotion and gender disparity in science in two ways. First, we have been able to construct a rich panel data sample that covers a broad range of research activities besides the usual bibliometric productivity measures (McDowell, Singell, and Ziliak [1999]). Second, our study focuses on a large European public research organization, while most of the literature relates to universities in the USA. The closest investigation to ours in terms of the data, general method, and issue is the work of Sabatier [2010] on female and male promotion at the French National Institute for Agricultural Research (INRA).

Our paper is organized as follows. Section 2 gives an overview of the empirical literature of gender differences in promotion in science. Section 3 explains the organizational setting of our study. Section 4 defines and describes in detail our data. Section 5 specifies our model and method of analysis briefly. Section 6 presents our estimates of the gender impact on the probability of 
being promoted and shows how promotion factors may affect differently female and male scientists. Section 7 summarizes and concludes.

\section{Literature overview}

In the early '40s, Robert Merton claimed that science should follow the norm of universalism according to which all scientists are judged objectively regardless of their "personal or social attributes” (Merton [1942]). If the norm applies to the promotion, highly-ranked positions should be attributed to men and women on the base of their scientific productivity. However, looking at recent statistics, it appears that female scientists tend to stay behind their male colleagues. "In the United States and Europe, around half of those who gain doctoral degrees in science and engineering are female - but barely one-fifth of full professors are women" (Nature Editorial [2013]). These facts have urged many scholars to study whether and to which extent observing few females in highly-ranked positions results from gender discrimination in promotion, from differences in research productivity, or personal choices, and constraints (Sonnert, G., Holton G.J. [1995]).

Universities and public research organizations are an excellent setting for studies on gender differences in the promotion since it is possible to construct direct measures of scientific productivity in various dimensions. Studies focusing on one single research field as well as studies extended to a broad set of fields have proliferated with sometimes divergent findings. For instance, focusing on economists, McDowell et al. [1999] find that women have a lower probability than men of being promoted from assistant to associate and from associate to full professor. Ginther and Kahn [2004] find that women also need a longer time to be promoted. Similar results are found by Weisshaar [2017] for the promotion to tenure in U.S. universities for assistant professors in 
sociology, computer science, and English. Kaminski and Geisler [2012] obtain the opposite result. Analyzing all fields of science and engineering in U.S. universities, they observe that men and women have comparable rates of promotion.

Most of the extant studies on promotion are based on productivity measures using standard bibliometric indicators of research output: the number of publications and citations received by scientists (Leahey [2007]). Few scholars like Weisshaar [2017] extend the set of research outputs by including detailed information on research books, edited volumes, textbooks, book chapters, and conference proceedings, as well as indications on scientists' fundraising activity (in particular - in the U.S. context - the number of grants and the total amount of funds received from the National Science Foundation).

Considering a comprehensive set of controls in analyzing promotion is crucial to avoid biased estimations, since, as claimed by Stewart, Ornstein, and Drakich ([2009], 63), "observed gender differences in promotion could reflect unmeasured differences between men and women faculty." Sociological studies confirm, for instance, that female and men scientists tend to distribute their time differently across academic activities. Usually, female scientists dedicate more time than their male colleagues to administrative tasks and mentoring students (Mason, Wolfinger, and Goulden [2013]).

Looking at the personal characteristics, dimensions like family characteristics might have a different impact on promotion for males and females. Extant studies seem to converge in finding that women are penalized by family and parental responsibilities (Bentley and Adamson [2003]), and evaluators might assume that women are losing commitment to work when they have a family (Manchester, Leslie, and Kramer [2010]). For this reason, after having children, women feel higher pressure than men to prove their productivity. Comparing women and men with children, 
Wolfinger, Mason, and Goulden [2008] find that women have lower chances to get the tenure or they get the tenure later. Policy instruments like the "stop the clock" policy, allowing pre-tenure faculty to postpone their promotion review, seem to have limited effects on promotion rates (Manchester et al. [2010]). Ginther and Kahn [2004] find that the rate of promotion is ten percentage points lower for female scientists when they have young children, while it appears to be higher for their male colleagues with young children. They ascribe this finding to stronger engagements of women in time-consuming activities external to research, in particular motherhood and young children care, and they also mention career interruptions when wives follow husbands' moves of occupation. Similarly, Rudd et al. [2008] find that marriage decreases women's chance to obtain academic tenure, contrary to men, in the fields of art history and humanities, two fields with a high proportion of women.

\section{Organizational setting}

Our study is conducted in the specific setting of the Centre National de la Recherche Scientifique (CNRS), and precisely in the context of one of its ten institutes, the Institut National de Physique (INP). CNRS is the largest governmental research organization in France and the leading research agency dedicated to basic research in Europe. ${ }^{1}$ CNRS, nowadays under the umbrella of the French Ministry of Higher Education, Research and Innovation, was founded in 1939 with the mission to advance knowledge in the areas of science and technology. INP covers the fields of theoretical physics, condensed matter, and optics and quantum physics. INP

\footnotetext{
${ }^{1}$ In fact, it is the largest one after CERN (Conseil Européen pour la Recherche Nucléaire) in Switzerland.
} 
researchers, technicians, and the permanent staff are recruited as civil servants, following general national administrative rules.

Mostly all researchers at CNRS are recruited through a competitive admission process in which candidates are evaluated based on their qualifications and research experience. Candidates are asked to submit a written application, including a curriculum vitae stating their scholarly background, previous professional experiences, and the list of publications, together with a research proposal indicating the domain and agenda they wish to pursue in the medium term. They need to satisfy some minimum requirements, like holding a doctoral degree or equivalent degree, but there are no nationality requirements. The selection is centralized in Paris, where shortlisted candidates are interviewed by a committee of experts in the field.

Permanent CNRS researchers are classified into two categories: Chargé de Recherche or CR and Directeur de Recherche or DR. Each of these categories has two sub-categories CR2 and CR1, and DR2 and DR1, respectively. The promotion from CR to DR, as well as within the two sub-categories, is based on scientific activity and seniority. ${ }^{2}$ In our analysis, we focus on the promotion from CR to DR, primarily based on the assessment of scientific performance.

As part of a nationwide effort to improve professional equality between women and men, CNRS created in 2001 a "Mission pour la place des femmes.” However, the share of female scientists working at CNRS increased only by 3,9\% in the last twenty years, from 30.1\% in 1999 to $34.0 \%$ in 2018 . Such a modest increase in the share of female working at CNRS would imply

\footnotetext{
${ }^{2}$ The official CNRS website reports the list of selection criteria: https://www.cnrs.fr/comitenational/doc/criteres/ce_sections_2012_16.pdf .
} 
that parity would only be reached in $2088 .{ }^{3}$ In an effort to stimulate the movement towards gender parity, in July 2018, a special “Comité parité et égalité” was created by the CNRS president.

The proportion of female researchers in the two major ranks of CR and DR varies much in the ten CNRS Institutes. Nowadays, women represent $37 \%$ of all CNRS CR and $27 \%$ of all CNRS DR, respectively (Pepin, Vacherand, and Dumitrascu [2019]). In 2011, the female presence ranged from a low share in mathematics and physics (17\% and 21\%) to a higher one in biology and human and social sciences, where women represent nearly half of the active researchers (42\% and $45 \%$ ).

\section{Data sources, variable construction, and descriptive statistics}

\section{Data sources}

To investigate the factors affecting the promotion rate of INP physicists to DR rank, we gathered a variety of data sources. We relied on administrative information available from CNRS, on bibliometric information mainly collected from Elsevier database Scopus, and on the answers of INP physicists to an online survey we performed.

We used the information obtained from the CNRS files to reconstruct the careers of INP physicists. In particular, we record the researchers' dates of entry at CNRS as a CR and their dates of promotion to DR. We relied on Scopus bibliometric database to extract their publication records. We also constructed other research productivity indicators taking advantage of the following public databases: the French repertory of national Ph.D. theses, the lists of research proposals to ANR the French “Agence Nationale de la Recherche," the PATSTAT database provided by the

\footnotetext{
${ }^{3}$ http://www.cnrs.fr/fr/cnrsinfo/creation-dun-comite-parite-egalite .
} 
European Patent Office (EPO), and CORDIS the European Union database of funded research projects.

In our online survey, we have considered the entire population of 1,085 INP physicists active in 2017, as part of a project focusing on the impact of family characteristics and research responsibilities on the gender publication gap (see Mairesse, Pezzoni, and Visentin [2019]). After three survey waves and deleting 17 incomplete answers, we have obtained a total of 604 respondents, corresponding to an overall response rate of 56\%. To evaluate the representativeness of our sample, we have been able to compare a individual characteristics such as gender, age, the field of specialization, and rank between respondents and non-respondents. As documented in Appendix A Table A1, we found limited differences. The broader difference concerns repornednts' gender with a proportion of 23\% (139) female physicists among the 604 respondents and only $14 \%$ (67) among the 481 non-respondents. In the survey, we asked researchers if they have children, and, if this was the case, their dates of birth. We also asked researchers to record the periods during which they had research responsibilities, distinguishing being head of a scientific team or having other research-related duties, such as being a member of a scientific advisory committee.

\section{Variable construction}

According to the CNRS guidelines for promotion, INP physicists to be promoted DR are judged on their scientific production, visibility, involvement in research projects, and managerial skills in leading research teams. We capture these promotion factors by constructing a set of variables measuring scientists' publication productivity, size of the professional network, mentoring, fundraising, technology transfer, and project management activities. Finally, we also consider variables constructed from our online survey to take into account scientists' family characteristics and research responsibilities. 
Precisely, we have constructed the following set of 18 variables:

- Female is a dummy variable that equals one for a female scientist and zero for a male scientist.

- Cumulated number of articles in $t-1$ measures the scientist's publication productivity for each year $t$ by counting the cumulated number of articles published in peer-reviewed journals until year $t-1$.

- Cumulated number of conference papers in $t-1$ measures the scientist's participation in conferences by counting the cumulated number of conference papers until year $t-1$.

- Average number of citations in $t-1$ measures the quality of the scientist's publication productivity. It counts the average number of citations received by the articles published in peer-reviewed journals or as conference papers until year $t-1 .^{4}$

- At least one EPO patent in $t-1$ is a proxy for the scientist's involvement in technology transfer activities. It is a dummy variable that equals one if the scientist has at least one patent application at the European Patent Office (EPO) until year $t$-1, zero otherwise. ${ }^{5}$

\footnotetext{
${ }^{4}$ The Average number of citations until $t-1$ is computed by dividing the cumulated numbers of all the yearly citations received by the publications until $t-1$ by the corresponding cumulated number of publications until $t-1$. Note that our bibliometric data only includes the total number of citations obtained by each publication from its publication year until 2019, and that we had to use a good enough approximation of average yearly citations, which we obtained by simply dividing the total number of citations until 2019 by the number of years from the publication year to 2019.

${ }^{5}$ In the matching exercise, to minimize the possibility of false matches between INP physicists and homonym inventors, we consider as valid matches only those for patents where CNRS appears among the applicants. This appears as a reasonable solution since CNRS includes in the promotion evaluation only technology transfer activities arising from research work at CNRS.
} 
- Cumulated number of collaborators in t-1 measures the size of the scientist's professional network. It counts the number of distinct co-authors listed in the scientist's articles with eight or fewer co-authors until year $t-1 .{ }^{6}$

- Cumulated number of Ph.D. theses supervised in t-1 measures the scientist's mentoring responsibilities by counting the cumulated number of Ph.D. theses supervised until year $t-1$.

- Cumulated years as head of a research team in t-1 measures the scientist's research responsibilities. It counts the cumulated number of years the scientist has been head of a research team or research laboratory until year $t-1$.

- Cumulated years of other research responsibilities in t-1 measures the scientist's participation in scientific advisory committee or scientific consultant activities. It counts the cumulated number of years the scientist has had such activities until year $t-1$.

- At least one ANR or EU grant in t-1 is a proxy for the scientist's fundraising skills. It is a dummy variable that equals one if the scientist has been the coordinator of at least one ANR or EU funded research project until year $t-1$, zero otherwise

- Family size until $t-1$ measures the scientist's number of children until year $t-1$.

\footnotetext{
${ }^{6}$ In physics, the size of teams and norms of authorship attribution might generate articles with long lists of co-authors, some of whom have marginally contributed to the research work (Sarsons [2017]). To capture only relationships that are likely to represent actual collaborations, we only counted the coauthors listed in papers with a limited number of co-authors (Gonzalez-Brambila, Veloso, and Krackhardt [2008]).
} 
- One child less than three years old in t-1 is a proxy for the scientist's involvement in taking care of a small child. It is a dummy variable that equals one if the scientist has one child born in the last three years, zero otherwise. ${ }^{7}$

- Age at $C R$ it measures the scientist's age at the time of the recruitment as CR. ${ }^{8}$

- Ph.D. in a Paris university, Ph.D. in a French university (not located in Paris), Ph.D. in a foreign university are three binary indicators proxying for differences in academic environment and experience. According to the scientist's place of graduation, they take value one or zero (with a sum equals to one).

- Ph.D. graduation year before 1991, Ph.D. graduation year 1991-2000, Ph.D. graduation year 2001-2017 are three binary indicators proxying for three contrasted periods during which scientists acquired their Ph.Ds. They take the value one or zero according to the scientist's year of Ph.D. graduation (with a sum equals to one). ${ }^{9}$

- Recruited as CR1 indicates that the scientist has been recruited at CNRS directly as CR1. It is a dummy variable equal to one if this is the case, and zero otherwise.

\footnotetext{
${ }^{7}$ We consider the age of three as a turning point for two reasons. First, it is the age until when parents are allowed by the French law to reduce their working hours and, second, the age at which a small child can start attending a nursery school (see Mairesse, Pezzoni, and Visentin [2019]).

${ }^{8}$ Although the scientist's age is strictly collinear with time, in event analysis and under the assumption of a linear effect of age on the logs of the hazard of being appointed DR, it is sufficient to measure it at the beginning of the time scale, that is here the recruitment as CR (see Allison [1984]).

${ }^{9}$ The information about the graduation year is only available for $65 \%$ of the scientists. When it is not available, we have been able to use the year of very first publication before entering CNRS for $23 \%$ of them, and have assumed they were 23 years old for the remaining $12 \%$.
} 
- Gender parity initiative (MPPF) is a dummy variable that equals one if the scientist entered INP as CR after 2001 (the year of the gender parity CNRS initiative "Mission pour la place des femmes”), zero otherwise.

- Section dummies are four binary indicators of the scientist's main fields of specialization: "Physical theories” (CNRS Section 2), “Condensed matter physics (structures and electronic properties)” (CNRS Section 3), “Atoms and molecules, optics and lasers, hot plasma physics” (CNRS Section 4), and "Condensed matter physics (organizations and dynamics)" (CNRS Section 5). They take the value one or zero according to the scientist's specialization (with a sum equals to one).

\section{Descriptive statistics}

Our study sample is an unbalanced panel of 7,805 observations for 604 INP scientists, of which 139 are women (23.0\%), and 465 are men (77.0\%). Each of them is an active researcher from when she enters at CNRS until 2017, which is the year of our online survey and last year of our study sample. Table 1 shows that overall, during our study period, 276 (45.7\%) researchers are promoted DR after 14.3 years, on average, and 328 (54.3\%) researchers stay CR without being promoted to DR for 11.7 years, on average.

Table 1: Promotion of INP scientists from CR to DR

\begin{tabular}{lccc|ccc|ccc}
\hline \multicolumn{1}{c}{ Numbers } & \multicolumn{3}{c|}{ Scientists } & \multicolumn{3}{c|}{$\begin{array}{c}\text { Scientist-year } \\
\text { Observations }\end{array}$} & \multicolumn{3}{c}{$\begin{array}{c}\text { Average number of } \\
\text { years at risk } \\
\text { of promotion }\end{array}$} \\
\hline & All & Female & Male & All & Female & Male & All & Female & Male \\
Recruited CR & 604 & 139 & 465 & 7805 & 1989 & 5816 & 12.9 & 14.3 & 12.5 \\
Promoted DR & 276 & 56 & 220 & 3967 & 888 & 3079 & 14.3 & 15.8 & 14.0 \\
Not promoted DR & 328 & 83 & 245 & 3838 & 1101 & 2737 & 11.7 & 13.3 & 11.2 \\
Share of promoted (\%) & 45.7 & 40.3 & 47.3 & 50.8 & 44.6 & 52.9 & -- & -- & -- \\
\hline
\end{tabular}

Note: For the individuals not promoted to DR, the average year duration is right-censored. 
We see also from Table 1 that 56 (40.3\%) female physicists are promoted DR after 15.8 years and their $220(47.3 \%)$ male colleagues after 14.0 years. The difference of years to be promoted from CR to DR for female and male physicists is of 1.8 years $(=15.8-14.0)$, a rather small number, but statistically highly significant (the P-value of the test between the two means equals 0.0076). Relatedly, 83 (59.7 \%) female researchers remain CR for 13.3 years until the end of the study period, while 245 (62.7 \%) male researchers remain CR for 11.2 years.

Table 2 reports the descriptive statistics for the time-invariant and time-variant variables. The descriptive statistics for the time-invariant variables are calculated over the sample of 604 researchers. Statistics for the time-variant variables are calculated over the 7,805 periods when the 604 researchers are at risk of promotion, namely from the year of entry at CNRS until the year of promotion to DR, or until 2017 if a researcher remains CR.

Without going into the details of this vast array of descriptive statistics, it is useful to point out the orders of magnitude of some variables and their differences between female and male researchers. As concerns the averages of the time-invariant variables, we observe that the differences between female and male researchers, in columns two and three, are often small and not statistically significant. By contrast, differences between researchers promoted and notpromoted to DR, in columns five and six, are often statistically significant.

In particular, male researchers appear more productive than their female colleagues. The average male physicist counts 23.4 cumulated peer-reviewed articles and 4.5 cumulated conference papers. Those papers, on average, received two citations each per year. The average female researcher counts 15.6 cumulated peer-reviewed articles and 2.9 conference papers, which received per year an average of 1.2 citations each. 
Table 2: Descriptive statistics.

\begin{tabular}{ccccccc}
$(1)$ & $(2)$ & $(3)$ & $(4)$ & $(5)$ & $(6)$ & $(7)$ \\
All & Female & Male & $\begin{array}{c}\text { P-val. } \\
2-3\end{array}$ & $\begin{array}{c}\text { Promoted } \\
\text { to DR }\end{array}$ & $\begin{array}{c}\text { Not } \\
\text { promoted }\end{array}$ & $\begin{array}{c}\text { P-val. } \\
5-6\end{array}$ \\
\hline
\end{tabular}

\begin{tabular}{|c|c|c|c|c|c|c|c|}
\hline \multicolumn{8}{|l|}{ Time-invariant covariates } \\
\hline \multicolumn{8}{|l|}{604 researchers (139 females, 465 males) } \\
\hline Female scientist & 0.23 & 1 & 0 & & 0.20 & 0.25 & 0.145 \\
\hline Male scientist* & 0.77 & 0 & 1 & & 0.80 & 0.75 & 0.145 \\
\hline Age at CR & 31.25 & 31.1 & 31.3 & 0.464 & 30.41 & 31.97 & 0.000 \\
\hline Recruited as CR1 & 0.22 & 0.23 & 0.22 & 0.746 & 0.25 & 0.20 & 0.069 \\
\hline Ph.D. in a Paris university & 0.35 & 0.29 & 0.37 & 0.105 & 0.35 & 0.35 & 0.955 \\
\hline Ph.D. in a French university & 0.44 & 0.41 & 0.45 & 0.379 & 0.41 & 0.46 & 0.238 \\
\hline Ph.D. in a foreign university (ref.) & 0.21 & 0.30 & 0.18 & 0.003 & 0.24 & 0.19 & 0.134 \\
\hline Ph.D. graduation year* & 1996 & 1995 & 1997 & 0.253 & 1990 & 2002 & 0.000 \\
\hline Ph.D. graduation year 2001-2017 & 0.40 & 0.37 & 0.42 & 0.311 & 0.08 & 0.68 & 0.000 \\
\hline Ph.D. graduation year 1991-2000 & 0.29 & 0.27 & 0.29 & 0.629 & 0.36 & 0.23 & 0.001 \\
\hline Ph.D. graduation year before 1991 (ref.) & 0.31 & 0.36 & 0.29 & 0.120 & 0.56 & 0.09 & 0.000 \\
\hline Section 2: Physical theories & 0.19 & 0.10 & 0.21 & 0.003 & 0.21 & 0.17 & 0.312 \\
\hline Section 3: Condensed matter physics (structures and electronic properties) & 0.24 & 0.21 & 0.25 & 0.349 & 0.22 & 0.25 & 0.467 \\
\hline Section 4: Atoms and molecules, optics and lasers, hot plasma physics & 0.29 & 0.31 & 0.29 & 0.596 & 0.29 & 0.29 & 0.939 \\
\hline Section 5: Condensed matter physics (organizations and dynamics) & 0.28 & 0.38 & 0.26 & 0.004 & 0.28 & 0.29 & 0.914 \\
\hline
\end{tabular}

\section{Time-variant covariates}

7805 periods at risk of promotion (1989 for females, 5816 for males)

Cumulated number of articles in $\mathrm{t}-1$

Cumulated number of conference papers in $\mathrm{t}-1$

Average number of citations in $\mathrm{t}-1$

Cumulated number of collaborators in $\mathrm{t}-1$

Cumulated number Ph.D. theses supervised in t-1

Cumulated years as head of a research team in t-1

Cumulated years with other research responsibilities in t-1

Family size in $\mathrm{t}-1$

One child less than 3 years old

At least one EPO patent in $\mathrm{t}-1$

At least one ANR or EU grant in $\mathrm{t}-1$

Gender parity initiative (MPPF)

Share of individuals with at least one child in the observation period*

Average number of publications at promotion time*

$\begin{array}{ccccccc}21.44 & 15.63 & 23.43 & 0.000 & 41.86 & 20.70 & 0.000 \\ 4.06 & 2.86 & 4.47 & 0.000 & 7.43 & 3.94 & 0.000 \\ 1.82 & 1.23 & 2.016 & 0.000 & 1.88 & 1.81 & 0.612 \\ 25.02 & 19.58 & 26.88 & 0.000 & 43.50 & 24.34 & 0.000 \\ 0.16 & 0.13 & 0.17 & 0.002 & 0.69 & 0.14 & 0.000 \\ 0.75 & 0.75 & 0.74 & 0.848 & 2.55 & 0.68 & 0.000 \\ 0.42 & 0.28 & 0.47 & 0.000 & 1.08 & 0.39 & 0.000 \\ 1.14 & 1.19 & 1.13 & 0.042 & 1.79 & 1.12 & 0.000 \\ 0.28 & 0.26 & 0.28 & 0.038 & 0.17 & 0.28 & 0.000 \\ 0.05 & 0.04 & 0.05 & 0.537 & 0.08 & 0.05 & 0.008 \\ 0.04 & 0.03 & 0.04 & 0.066 & 0.05 & 0.04 & 0.183 \\ 0.38 & 0.33 & 0.40 & 0.000 & 0.19 & 0.39 & 0.000 \\ 0.75 & 0.79 & 0.73 & 0.168 & 0.81 & 0.70 & 0.001 \\ 43.46 & 32.98 & 46.59 & 0.000 & 49.29 & 38.55 & 0.000\end{array}$

Note: Column 4 shows the P-value of the tests for mean equality between females (Column 2) and males (Column 3 ), while Column 7 shows the P-value of the tests for mean equality between researchers promoted to DR (Column 5) and not promoted (Column 6). The average values for the time-invariant covariates are calculated at the researcher level, while the time-variant covariates are calculated as an average for all the period at risk of promotion. *Average statistics mentioned in the text, but not entering in the econometric analysis.

Otherwise, male researchers have a larger professional network than female researchers, counting respectively, on average, 26.9 and 19.6 collaborators. During our period of observation, a male researcher supervised, on average, $0.17 \mathrm{Ph}$.D. theses, while a female researcher supervised, 
on average, 0.13 of them. The small fraction of theses supervised is explained by the French institutional situation whereby typically Ph.D. doctorates are delivered by universities, and not by public research institute like the CNRS. However, CNRS researchers are often teaming up with their university colleagues, working in the same buildings and labs and this collaboration ending with sharing Ph.D. theses (see Lissoni et al. [2011]; Mairesse and Pezzoni [2015] for two comparative analyses of scientific productivity and academic promotion of French CNRS and university physicists).

Scientists’ fundraising and technology transfer activities appear to be limited and are as frequent for male and female researchers, with only $5 \%$ of the observations referring to a scientist with at least one EPO patent and $4 \%$ to a scientist who has been coordinating an ANR or EU grant.

Concerning the online survey variables, female and male researchers spend, on average, the same time as head of a research team (0.75 and 0.74). By contrast, the time devoted to other responsibilities is much larger and significantly higher for male researchers than for their female colleagues, respectively 0.47 years and $0.28 .{ }^{10}$ On average, the family size, as measured by total number of children, and the child less than three-years old dummy are weakly statistically different between female and male scientists, and respectively equal $1.19 \%$ and $26 \%$ for female and 1.13\% and $28 \%$ for male. ${ }^{11}$

\footnotetext{
${ }^{10}$ The average figures of time during which researchers have responsibilities may appear small because they include the periods of inactivity. If we exclude the periods of inactivity, male researchers are respectively responsible for a research team and in charge of other responsibilities for 4.54 and 4.49 years, while female researchers for 4.67 and 3.32 years

${ }^{11}$ The average family size and percentage of less than three-years old child include the researchers with no children and periods when children are older. If we exclude these cases, the average family sizes are equal to 1.95 and 1.82 for male and female researchers respectively, and the average percentages for less than three-years old child are equal to 0.49 and 0.40 .
} 
Finally, the differences in the time-variant variables between the promoted and not promoted to DR scientists are, like the ones for the time-invariant variables, both strongly positive and statistically highly significant. There are nonetheless two not surprising exceptions. The less than three-years child variable and the gender parity initiative dummies are, on average, about twice higher and statistically more significant for the physicists non-promoted to DR than for the ones promoted.

\section{Model and method}

We rely on the statistical models and methods of 'survival' or 'event history analysis' to assess the rate of occurrence or 'hazard rate' of the promotion of INP physicists from CR to DR (Allison [1984]; Wooldridge [2002]). ${ }^{12}$ The hazard rate function $h(t)$ is defined by the ratio between the probability that the event occurs at time $t$ and the probability that the event has not yet occurred until $t: h(t)=f(t) /(1-F(t))$, where $f(t)$ is the probability density function, and (1$F(t))$ is the survival function equal to one minus the cumulated density function $F(t)$.

As a first exploratory analysis, we follow the standard practice of computing and representing the 'Kaplan-Meier’ survival function graphically. We plot the survival fuction separately for female and male researchers. We find that the log-rank test of equality between the two Kaplan-Meir survival functions is rejected with a P-value of 0.0004 (Chi2 =12.51). We also

\footnotetext{
12 Survival analysis or event history analysis refer basically to the same statistical methods, with names depending on the various fields of application. For example, survival is mainly used in epidemiology or actuaruial sciences when the interest is in forecasting the time to death, or event history analysis in social sciences or economics on topics such as labor market mobility and unemployment spells; or else reliability or failure studies in engineering; etc.
} 
see in Figure 1 that the average survival rate for female physicists as CR is higher than for males in all periods, meaning that the female average promotion rate to DR is lower than the males' one.

Figure 1: Kaplan-Meier survival function estimates by gender

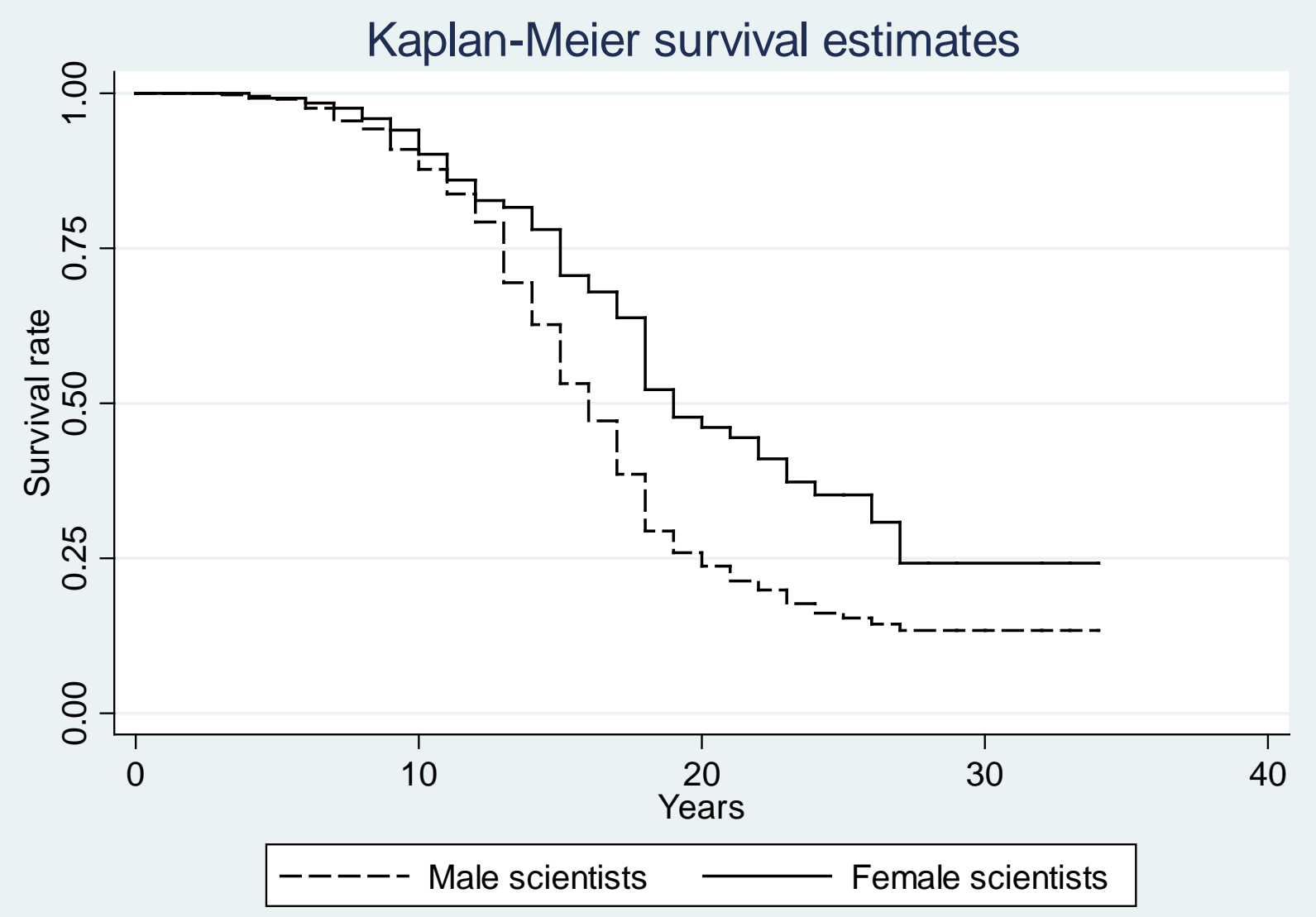

Note: The $\mathrm{x}$-axis years is the time elapsed from the recruitment as CR to the promotion to DR.

Beyond this exploratory analyses, the core of our study is to account for the observed differences in the hazard rates of promotion between female and male scientists based on the various factors of promotion, which we have been able to measure.

We estimate the following model:

$$
h_{i}(t)=h_{0}(t) e^{\left(\beta_{1} x_{1, i}+\beta_{2} x_{2, i}(t-1)\right)} \quad \text { Equation } 1
$$


where $\beta_{1}$ and $\beta_{2}$ are vectors of the parameters to estimate, $h_{0}(t)$ is the unknown baseline hazard function that relates the hazard rate to time, $x_{1}$ is a vector of variables including all the timeinvariant covariates, and $x_{2}(t-1)$ is a vector of variables including all the time-variant covariates lagged by one year. To estimate the vectors of parameters $\beta_{1}$ and $\beta_{2}$, we use Cox's partial likelihood estimator for proportional hazard models (see Danell and Hjerm [2013]; Ginther and Hayes [1999] for similar approaches). The partial likelihood estimation allows us to let unspecified the functional form of $h_{0}(t)$. As a robustness check, in Appendix B1 we report parametric estimations where a Weibull distribution is assumed as the functional form of $h_{0}(t)$. As explained we find that the results are qualitatively the same.

To clarify the interpretation of the parameters $\beta$ s, the most straightforward example is to consider a simplified version of Equation 1 including only the dummy variable Female: $h_{i}(t)=h_{0}(t) e^{\left(\beta f \text { female }_{i}\right)}$. We find that the estimated $\widehat{\beta_{\text {female }}}$ equals 0.603 with a standard error of 0.086 . The value 0.603 corresponds to the ratio between the hazard rate of promotion of a female scientist and the hazard rate of promotion of a male scientist. We calculate the variation of the hazard rate of promotion for a female scientist as $0.603-1$, corresponding to a $39.7 \%$ lower rate of promotion for females with respect to her male counterpart. This specification corresponds to the benchmark equation estimated in the first column of Table 3.

\section{Is there gender equality in promotion rates?}

In Table 3, we present estimates of four Cox's regressions, including time-invariant and time-variant variables described in Section 4 and documented in Table 2 of the descriptive statistics. 
Table 3: Event history analysis for promotion to DR

3: Event history analysis for promotion to DR

(1) (2)

(3)

(4)

Hazard ratio Hazard ratio Hazard ratio Hazard ratio

Female

$0.603 * * *$

$0.607 * * *$

$0.837 \quad 0.855$

Cumulated number of articles in t-1

(0.086)

(0.101)

(0.123)

(0.147)

$1.022 * * * \quad 1.028 * * *$

(0.00260) (0.004)

Cumulated number of conference papers in $\mathrm{t}-1$

$0.997 \quad 0.996$

$(0.00516) \quad(0.00688)$

Average number of citations in $\mathrm{t}-1$

1.035* $1.065 * * *$

(0.0205) (0.025)

At least one EPO patent in t-1

1.087

Cumulated number of collaborators in $\mathrm{t}-1$

(0.269)

0.994*

(0.003)

Cumulated number Ph.D. theses supervised in t-1

$1.182 * *$

(0.080)

Cumulated years as head of a research team in t-1

$1.091 * * *$

(0.019)

Cumulated years of other research responsibilities in t-1

0.982

(0.028)

At least one ANR or EU grant in t-1

0.753

(0.248)

Family size in t-1

$1.110 * *$

1.085

One child less than 3 years old

(0.055)

(0.058)

0.794

0.759

(0.133)

(0.128)

Age at CR

1.008

1.025

(0.033)

(0.033)

Ph.D. from a Paris university

0.852

0.848

(0.153)

(0.161)

Ph.D. from a French university

0.984

0.844

(0.162)

(0.156)

Ph.D. graduation year 2001-2017

0.637

0.712

(0.208)

(0.242)

Ph.D. graduation year 1991-2000

0.889

0.830

(0.131)

(0.133)

Recruited as CR1

1.944***

$2.010 * * *$

(0.404)

$(0.405)$

1.188

0.880

(0.259)

(0.216)

Section dummies

Pseudo R squared

\begin{tabular}{cccc} 
No & Yes & No & Yes \\
0.004 & 0.02 & 0.028 & 0.066 \\
604 & 604 & 604 & 604 \\
328 & 328 & 328 & 328 \\
7,805 & 7,805 & 7,805 & 7,805 \\
\hline
\end{tabular}

Number of scientists

Number of scientists not promoted (censored)

Observations

7,805

7,805

7,805

Note: Cox's partial likelihood estimator for the proportional hazard model is used. Standard errors are clustered around scientists. ${ }^{a}$ Reference category is Ph.D. in a foreign university; ${ }^{b}$ Reference category is Ph.D. graduation year before 1991 . 
In the first column of Table 3, we show the benchmark model including only the female dummy as explanatory variable. We find, as already shown by the exploratory analysis reported in the previous section, that the rate of promotion to DR is $39.7 \%$ lower for female physicists than for their male colleagues. In the second column, we include as promotion factors the vector of seven biographic and family characteristics. Only two of these characteristics are statistically significant. The Recruited as CR1 dummy variable is highly significant, implying that the estimated rate of promotion is $94.4 \%$ higher for physicists recruited directly as CR1 than for those recruited as CR2. The Family size variable is significant at a 5\% confidence level, implying that the estimated rate of promotion is $11 \%$ higher, on average, for each additional child in the physicist’s family.

In the third column, we consider only standard scientific productivity indicators of publication quantity and quality such as the Cumulated number of articles, Cumulated number of conference papers and Average number of citations. We find that, as expected, the number of articles and average number citations received have both positive and statistically significant effect. ${ }^{13}$ Precisely, adding one article to the researcher's stock of peer-reviewed articles and one citation per year to the stock of citations received increase respectively by $2.2 \%$ and $3.5 \%$ the promotion rate of physicists. We also find that including these three variables in the regression exercise is enough to account for the gender inequality gap in promotion to DR recorded in the regressions reported in columns one and two. The coefficient of the estimated female hazard ratio is not anymore significantly smaller than one. It is now equal to 0.837 (with standard error 0.123 ),

\footnotetext{
${ }^{13}$ The correlation between the Cumulated number of conference papers and the Cumulated number of articles equals to 0.47 overall, and 0.48 and 0.47 for female and male researchers separately. These high values partly explain why Cumulated number of conference papers does not show statistical significance, when included in the Cox's regressions together the Cumulated number of conference papers.
} 
instead of 0.607 (and standard error 0.101), and corresponds to an average rate of promotion $16.3 \%$

lower for female physicists than their male colleagues instead of the $39.3 \%$ reported in the second column.

In the fourth column, we include our complete set of covariates. We find that the coefficient of the female dummy remains unchanged and not significantly smaller than one. The variables (Cumulated number of articles and Average number of citations) remain significant with a positive impact on the promotion rate to DR of physicists. Looking at the other promotion factors, we see that one more Ph.D. thesis supervised (Cumulated number of Ph.D theses supervised) and one more year as head of a research team (Cumulated years as head of a research team) boost respectively by $18.2 \%$ and $9.1 \%$ promotion rate. We also observe that the Cumulated number of collaborators has a weakly significant negative impact impact, showing that having one more collaborator dampen the promotion rate by $0.6 \%$.

\section{Does promotion factors' impact differ for male and female researchers?}

The results shown in Table 3 can be enriched by allowing promotion factors to have different effects for female and male researchers. To do so, we interact with the Female dummy variable all the eighteen promotion factors included in the regression model reported in the column four of Table 3. The results are reported in Table 4, where the first column shows the estimated hazard ratio coefficients, and the second column reports the raw coefficients estimated using the Cox's regression. Reporting the raw coefficients allow us to recover the variation of the promotion rate for female scientists (not directly shown in the interacted regressions). The promotion rate variation for female scientists is equal to the exponential of the linear combination of the raw coefficients of the non-interacted variable and the female-interacted variable minus one. For 
instance, the variation of the promotion rate for a female scientist spending one more year as the head of a research team is calculated as $[\exp (0.0667+0.0642)-1] * 100=14.0 \%$, where 0.0667 and 0.0642 are the raw coefficients of the variables Cumulated years as head of a research team and Female*Cumulated years as head of a research team reported in column two of Table 4. We obtain that an additional year spent as the head of a research team accounts for an increase of the promotion rate of female scientists of $14.0 \%$, about twice the value estimated for their male colleagues of $6,9 \%$, equal to $[\exp (0.0667)-1] * 100$.

Table 4: Event history analysis for promotion to DR including all interactions between the Female variable and all other variables.

\begin{tabular}{|c|c|c|}
\hline & $\begin{array}{c}(1) \\
\text { Hazard ratio }\end{array}$ & $\begin{array}{c}(2) \\
\text { Raw coefficients }\end{array}$ \\
\hline Female & $\begin{array}{c}0.213 \\
(0.785)\end{array}$ & $\begin{array}{l}-1.546 \\
(3.681)\end{array}$ \\
\hline Cumulated number of articles in t-1 & $\begin{array}{c}1.033^{* * *} \\
(0.005)\end{array}$ & $\begin{array}{c}0.033^{* * *} \\
(0.005)\end{array}$ \\
\hline Female ${ }^{*}$ Cumulated number of articles in $t-1$ & $\begin{array}{c}0.995 \\
(0.009)\end{array}$ & $\begin{array}{l}-0.005 \\
(0.009)\end{array}$ \\
\hline Cumulated number of conference papers in $\mathrm{t}-1$ & $\begin{array}{c}0.994 \\
(0.007)\end{array}$ & $\begin{array}{c}-0.006 \\
(0.007)\end{array}$ \\
\hline Female ${ }^{*}$ Cumulated number of conference papers in $t-1$ & $\begin{array}{c}1.013 \\
(0.028)\end{array}$ & $\begin{array}{c}0.013 \\
(0.028)\end{array}$ \\
\hline Average number of citations in $\mathrm{t}-1$ & $\begin{array}{c}1.054 * * \\
(0.024)\end{array}$ & $\begin{array}{c}0.053 * * \\
(0.023)\end{array}$ \\
\hline Female*Average number of citations in $t-1$ & $\begin{array}{c}1.175 \\
(0.130)\end{array}$ & $\begin{array}{c}0.161 \\
(0.110)\end{array}$ \\
\hline At least one EPO patent in $\mathrm{t}-1$ & $\begin{array}{c}1.295 \\
(0.322)\end{array}$ & $\begin{array}{c}0.258 \\
(0.249)\end{array}$ \\
\hline Female $^{*}$ At least one EPO patent in $t-1$ & $\begin{array}{c}0.420 \\
(0.288)\end{array}$ & $\begin{array}{l}-0.868 \\
(0.685)\end{array}$ \\
\hline Cumulated number of collaborators in $\mathrm{t}-1$ & $\begin{array}{c}0.989 * * * \\
(0.004)\end{array}$ & $\begin{array}{c}-0.011 * * * \\
(0.004)\end{array}$ \\
\hline Female ${ }^{*}$ Cumulated number of collaborators in $t-1$ & $\begin{array}{c}1.006 \\
(0.010)\end{array}$ & $\begin{array}{c}0.006 \\
(0.010)\end{array}$ \\
\hline Cumulated number Ph.D. theses supervised in t-1 & $\begin{array}{c}1.238^{* * *} \\
(0.094)\end{array}$ & $\begin{array}{c}0.213^{* * *} \\
(0.076)\end{array}$ \\
\hline Female ${ }^{*}$ Cumulated number Ph.D. theses supervised in $t-1$ & $\begin{array}{c}1.051 \\
(0.198)\end{array}$ & $\begin{array}{l}0.0493 \\
(0.188)\end{array}$ \\
\hline Cumulated years as head of a research team in t-1 & $\begin{array}{c}1.069 * * * \\
(0.024)\end{array}$ & $\begin{array}{c}0.0667 * * * \\
(0.022)\end{array}$ \\
\hline Female ${ }^{*}$ Cumulated years as head of a research team in $t-1$ & $\begin{array}{c}1.066 \\
(0.043)\end{array}$ & $\begin{array}{l}0.0642 \\
(0.040)\end{array}$ \\
\hline Cumulated years of other research responsibilities in t-1 & $\begin{array}{c}0.977 \\
(0.0301)\end{array}$ & $\begin{array}{c}-0.0229 \\
(0.031)\end{array}$ \\
\hline Female*Cumulated years of other research responsibilities in $t-1$ & $\begin{array}{c}1.074 \\
(0.115)\end{array}$ & $\begin{array}{c}0.071 \\
(0.107)\end{array}$ \\
\hline At least one ANR or EU grant in t-1 & $\begin{array}{c}0.522 \\
(0.210)\end{array}$ & $\begin{array}{c}-0.650 \\
(0.402)\end{array}$ \\
\hline Female*At least one ANR or EU grant in $t-1$ & $\begin{array}{c}5.475 * * \\
(3.971)\end{array}$ & $\begin{array}{l}1.700^{* * *} \\
(0.725)\end{array}$ \\
\hline Family size in t-1 & $\begin{array}{l}1.104^{*} \\
(0.064)\end{array}$ & $\begin{array}{c}0.099 \\
(0.058)\end{array}$ \\
\hline
\end{tabular}




\begin{tabular}{|c|c|c|}
\hline Female $*$ Family size in $t-1$ & $\begin{array}{c}0.915 \\
(0.158)\end{array}$ & $\begin{array}{c}-0.089 \\
(0.172)\end{array}$ \\
\hline One child less than 3 years old & $\begin{array}{c}0.759 \\
(0.135)\end{array}$ & $\begin{array}{c}-0.276 \\
(0.178)\end{array}$ \\
\hline Female*One child less than 3 years old & $\begin{array}{c}1.070 \\
(0.480)\end{array}$ & $\begin{array}{c}0.068 \\
(0.448)\end{array}$ \\
\hline Age at CR & $\begin{array}{c}1.020 \\
(0.034)\end{array}$ & $\begin{array}{c}0.020 \\
(0.033)\end{array}$ \\
\hline Female*Age at CR & $\begin{array}{l}1.047 \\
(0.125)\end{array}$ & $\begin{array}{l}0.0456 \\
(0.119)\end{array}$ \\
\hline Ph.D. from a Paris university ${ }^{a}$ & $\begin{array}{l}1.137 \\
(0.264)\end{array}$ & $\begin{array}{c}0.128 \\
(0.232)\end{array}$ \\
\hline Female*Ph.D. from a Paris university & $\begin{array}{l}0.375^{*} \\
(0.212)\end{array}$ & $\begin{array}{l}-0.980^{*} \\
(0.566)\end{array}$ \\
\hline Ph.D. from a French university ${ }^{a}$ & $\begin{array}{c}1.002 \\
(0.239)\end{array}$ & $\begin{array}{c}0.002 \\
(0.239)\end{array}$ \\
\hline Female*Ph.D. from a French university & $\begin{array}{c}0.533 \\
(0.232)\end{array}$ & $\begin{array}{l}-0.630 \\
(0.435)\end{array}$ \\
\hline Ph.D. graduation year 2001-2017b & $\begin{array}{c}0.668 \\
(0.245)\end{array}$ & $\begin{array}{c}-0.403 \\
(0.366)\end{array}$ \\
\hline Female*Ph.D. graduation year 2001-2017 & $\begin{array}{c}1.229 \\
(1.121)\end{array}$ & $\begin{array}{c}0.207 \\
(0.912)\end{array}$ \\
\hline Ph.D. graduation year $1991-2000^{\mathrm{b}}$ & $\begin{array}{c}0.813 \\
(0.144)\end{array}$ & $\begin{array}{l}-0.207 \\
(0.177)\end{array}$ \\
\hline Female*Ph.D. graduation year 1991-2000 & $\begin{array}{l}1.037 \\
(0.473)\end{array}$ & $\begin{array}{c}0.036 \\
(0.456)\end{array}$ \\
\hline Recruited as CR1 & $\begin{array}{c}2.265^{* * * *} \\
(0.509)\end{array}$ & $\begin{array}{c}0.818^{* * *} \\
(0.225)\end{array}$ \\
\hline Female*Recruited as CR1 & $\begin{array}{c}0.928 \\
(0.534)\end{array}$ & $\begin{array}{l}-0.0748 \\
(0.576)\end{array}$ \\
\hline Gender parity initiative (MPPF) & $\begin{array}{c}0.912 \\
(0.247)\end{array}$ & $\begin{array}{c}-0.092 \\
(0.271)\end{array}$ \\
\hline 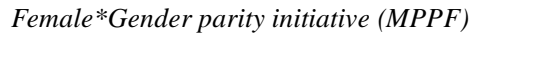 & $\begin{array}{c}0.822 \\
(0.526)\end{array}$ & $\begin{array}{c}-0.196 \\
(0.640)\end{array}$ \\
\hline Section dummies & Yes & Yes \\
\hline Section dummies interacted with Female & Yes & Yes \\
\hline Pseudo R squared & 0.0734 & 0.0734 \\
\hline Number of scientists & 604 & 604 \\
\hline Number of scientists not promoted (censored) & 328 & 328 \\
\hline Observations & 7,805 & 7,805 \\
\hline
\end{tabular}

Note: Cox's partial likelihood estimator for the proportional hazard model. Column 1 reports Hazard ratios, while Column 2 reports raw coefficients which are useful to discuss the effects of the interactions. Standard errors are clustered around scientists. ${ }^{a}$

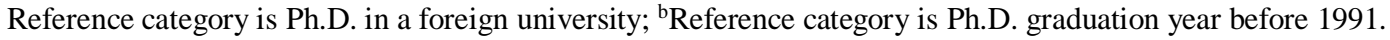

As expected, scientific productivity plays a crucial role in the promotion to DR for both female and male scientists. The effects of publication quantity and quality (Cumulated number of articles and Average number of citations) are both positive and significant. Precisely, adding one article to their stocks of peer-reviewed articles augments by $3.3 \%$ and $2.8 \%$ the promotion rates to DR of male and female researchers, respectively. Looking at the significance of the interaction coefficient Female*Cumulated number of articles we find that the difference between these two effects is not statistically significant. Similarly, increasing by one citation the Average number of citations boosts by $5.4 \%$ and $23.8 \%$ the promotion rates of male and female researchers, 
respectively. Although the magnitude of these effects appears much larger for the female than for the male researchers, the difference is not statistically significant.

Surprisingly, the effect of Cumulated number of collaborators is detrimental for male researchers, decreasing their promotion rate by $1 \%$ for each additional collaborator, while it has no effect for female researchers (with an interaction term not significantly different from zero). On the contrary, the effect of the Cumulated number Ph.D. theses supervised is beneficial for male researchers increasing their rate of promotion by $23.8 \%$ for each additional Ph.D., while it has no effect for female researchers. Although the difference between the two effects is large, it is not statistically significant. The effects of Cumulated years with other responsibilities and At least one EPO patent are not significant for the promotion to DR, neither for men nor for women. Having an ANR or EU grant increases the promotion rate to DR for female researchers by $185.9 \%$ if compared to the promotion rate of a female researchers with no grants. Grants have no effect for male researchers. ${ }^{14}$

Concerning the researcher's family and personal characteristics, the effect of Family size appears to be favorable to male researchers, increasing their promotion rate by $10.4 \%$ while it does not affect female researchers. Having One child born in the last 3 years does not affect the promotion to DR neither for men nor for women. We find that Age at $C R$ does not affect the promotion rate and that being directly Recruited as CR1 significantly shorten the path toward the promotion to DR for male researchers, but not for female researchers (with an interaction term not significantly different from zero). Having a Ph.D. from a French University (not located in Paris),

\footnotetext{
${ }^{14}$ Note that 54 male researchers and 20 female researchers obtain a grant during our study period. Among them, 11 males and 4 females are promoted to DR. For these males it took, on average, 3.9 years to be promoted after obtaining a grant, while for the 4 females it took only 3.5 years.
} 
significantly decreases the rate of promotion for female researchers with respect to female physicists who obtain their Ph.D. from a foreign university. We find that the Ph.D. graduation year indicators do not affect the promotion rate either for men or women. Finally, we observe that promotion rates are not significantly different after the implementation of the Gender Parity Initiative "Mission Pour la Places des Femmes".

We have tested the robustness of our results to different model estimation strategies, by considering a series of four robustness checks, which we present in Appendix B in the same format than our main results in Tables 3 and 4. Specifically, in Appendix B1, we use a parametric proportional hazard model. In Appendix B2, we run separated regressions considering the promotion to intermediate positions. In Appendix B3 we address the concern that scientists might experience alternative 'exit modes', and in Appendix B4, we use a parametric model with unshared frailty. These tests basically confirm our main results, while they also bring up interesting new points.

\section{Discussion and conclusions}

This paper investigates the factors affecting the main career advancement of scientists at INP, the physics institute of CNRS. Our central result is that differences in research productivity account entirely for the gender gap in the promotion to DR of INP physicists. This result shows that INP successfully embraces the "universalism" norm according to which scientist career reward should be assigned only on the base of scientific productivity (Merton [1942]). It also supports the so-called "difference model” assuming that the observed gender gaps in promotion for scientists of equal research productivity do not necessarily imply gender discrimination ("the deficit model"), but can reflect differences in an individual situation, in the institutional 
environment, as well as imperfect, incomplete and error-ridden measures of productivity (Sonnert and Holton [1995]; Ceci and Williams [2011]).

We summarize in Table 5 the covariate effects on the promotion to DR of female and male scientists separately, when they are statistically significant. We recall, in the first and second columns, the estimated impacts on rate of promotions for female and male scientists. In the third column we report if the differences between these estimates are statistically significant (S) or not (NS). ${ }^{15}$ In the fourth and fifth columns, we present the estimates in terms of 'equivalent number of articles', that is using as our unit of measure the impact of having one more article in peerreviewed journals.

Table 5:Significant impacts of promotion factors by gender

\begin{tabular}{|c|c|c|c|c|c|}
\hline & (1) & (2) & (3) & (4) & (5) \\
\hline & \multicolumn{3}{|c|}{$\begin{array}{c}\text { Average impact on rate } \\
\text { of promotionin } \%\end{array}$} & \multicolumn{2}{|c|}{$\begin{array}{l}\text { Equivalent number of } \\
\text { articles }^{\mathrm{b}}\end{array}$} \\
\hline & Female & Male & Difference $^{a}$ & Female & Male \\
\hline Cumulated number of articles & 2.77 & 3.31 & NS & 1.00 & 1.00 \\
\hline Average number of citations & 23.85 & 5.41 & NS & 8.60 & 1.64 \\
\hline Cumulated number of collaborators & NS & -1.08 & NS & NS & -0.33 \\
\hline Cumulated number Ph.D. theses supervised & NS & 23.75 & NS & NS & 7.18 \\
\hline Cumulated years as head of a research team & 14.00 & 6.91 & NS & 5.05 & 2.09 \\
\hline At least one ANR or EU grant & 185.87 & NS & S & 67.01 & NS \\
\hline Family size & NS & 10.41 & NS & NS & 3.15 \\
\hline Ph.D. from a Paris university ${ }^{c}$ & NS & NS & -62.48 & NS & NS \\
\hline Ph.D. from a French university ${ }^{\mathrm{c}}$ & -46.62 & NS & NS & -16.81 & NS \\
\hline Recruited as CR1 & NS & 126.53 & NS & NS & 38.24 \\
\hline
\end{tabular}

${ }^{\mathrm{a}} \mathrm{S}$ and NS stand respectively for statistically and not statistically significant; ${ }^{\mathrm{b}}$ Equivalent impact in terms of number of articles is obtained as the ratio between the variation of the promotion rate due to the variable considered and the variation of the promotion rate due to the publication of an additional article; ${ }^{\mathrm{C}} \mathrm{Ph}$.D. from a foreign university is taken as the reference.

\footnotetext{
${ }^{15}$ The tests of non statistically significant impacts for the rate of promotion of female scientists and their differences with male scientists are all very precise, reflecting the large number of observations for both female and male scientists in our study sample (see Table 2).
} 
We find that the most widely used bibliometric indicators of productivity, i.e., the count of peer-reviewed articles and yearly citations received, have significant positive effects on the promotion rates for both female and male scientists. We observe a variation of $2.77 \%$ and $3.31 \%$ for each additional article published by female and male scientists, respectively. We observe similarly an increase of $23.85 \%$ and $5.41 \%$ for each additional citation received by female and male scientists, respectively. We also see that for female scientists the impact of one additional citation is equivalent to publishing $8.6(\sim 23.8 / 2.8)$ articles, while for their male colleagues it is equivalent $1.6(\sim 5.4 . / 3.3)$ articles, that is more than five times less. Carrying research responsibilities as head of a research team is the only other case where the impact on promotion rate is significant for both female and male scientists. We find each additional year as head of a research team being equivalent as 5.0 articles more for female scientists and 2.1 for male scientists, that is more than twice less.

Among the various possibilities, Table 5 reveals simply two patterns whereby factors of promotion have significant impacts on male scientists but with no significant differences with female scientists (four cases), and on the opposite (two cases). For male researchers, each additional collaborator is equivalent to having 0.3 articles less in their publication portfolio, while it is not detrimental for female researchers. For male researchers, mentoring one Ph.D. student is equivalent to publishing 7.2 articles. This is not the case for female researchers. Surprizingly, each additional child in the family is equivalent to having 3.1 articles for male researchers; however, it does not affect the promotion rate of female researchers. Being recruited as CR1 is equivalent as having 38.2 articles for male researchers until their promotion to DR, not for female researchers.

Having obtained an ANR or EU grant boosts the promotion rate for female scientists as much as publishing 67.0 articles until their promotion to DR. This is not the case for male scientits. 
For female scientists, having a Ph.D. from a French university not located in Paris is equivalent to publishing 16.8 less articles than researchers who have a Ph.D. from a foreing university, while it is not significant for male scientists. Having a Ph.D. from a French university located in Paris is not different from having a Ph.D. from a foreign university, both for female and male scientists.

Taking them at face value, our findings can provide hints to researchers wishing to leverage specific factors of promotion to be promoted to DR. They suggest that both female and male researchers should invest in increasing their peer-reviewed article publications and citation scores. However, men have more options for a faster promotion than women, who particurlarly benefit from having research responsibilities as head of a research team and being successful in raising funds for research projects.

While our findings on the beneficial impacts of publication and citation scores are expected and in line with previous studies, others findings deserve discussion. Our estimates on the negative effect of having an higher number of collaborators for male researchers might be associated with the difficulties in attributing credit for teamwork in larger teams (Sarsons [2017]). The estimated effects of mentoring are positive for both female and male researchers, but statistically significant only in the case of male researchers. Previous studies recognize that women are frequently committed to teaching and taking care of students (Mason et al. [2013]). This behavior might generate in promotion committees the feeling that devoting time and effort to coaching students is normal for many female researchers. For men, in contrast, the choice of mentoring might be interpreted as a sign of specific commitments and viewed as a positive signal for promotion to DR. Similar signals are associated with leading a research team, but in this case, female researchers benefit more than their male counterparts. When female researchers lead a research team, this 
engagement is viewed by promotion committees as proof that they have the scientific maturity and competence to be promoted to DR.

As a final remark of caution, while we find results showing that policy recommendations and rules supporting gender equality for promotion are on the whole effective, they may be primarily driven by the fact they concern highly-ranked institutions as CNRS and the INP. That may not be the case of other institutions doing scientific research (McDowell et al. [1999]). It would certainly be enlightening to emulate the present study for other CNRS institutes than INP, as well as focusing again on the field of Physics discipline but in French universities, and beyond in other countries.

\section{References}

Allison, Paul David. [1984]. Event History Analysis Regression for Longitudinal Event Data. Beverly Hills, Calif.: Sage Publications.

Bentley, Jerome T. and Rebecca Adamson. [2003]. "Gender Differences in the Careers of Academic Scientists and Engineers: A Literature Review. Special Report.”

Ceci, Stephen J. and Wendy M. Williams. [2011]. "Understanding Current Causes of Women's Underrepresentation in Science.” Proceedings of the National Academy of Sciences 108(8):3157-62.

Cox, David R. [1972]. "Regression Models and Life-Tables.” Journal of the Royal Statistical Society: Series B (Methodological) 34(2):187-202.

Danell, R. and M. Hjerm. [2013]. “The Importance of Early Academic Career Opportunities and Gender Differences in Promotion Rates.” Research Evaluation 22(4):210-14.

Fox, M. F. [2001]. “Women, Science, and Academia: Graduate Education and Careers.” Gender \& Society 15(5):654-66. 
Ginther, Donna K. and Kathy J. Hayes. [1999]. "Gender Differences in Salary and Promotion in the Humanities.” American Economic Review 89(2):397-402.

Ginther, Donna K. and Shulamit Kahn. [2004]. "Women in Economics: Moving Up or Falling Off the Academic Career Ladder?” Journal of Economic Perspectives 18(3):193-214.

Gonzalez-Brambila, Claudia N., Francisco M. Veloso, and David Krackhardt. [2008]. “Social Capital and the Creation of Knowledge.” SSRN Electronic Journal.

Kaminski, D. and C. Geisler. [2012]. "Survival Analysis of Faculty Retention in Science and Engineering by Gender.” Science 335(6070):864-66.

Leahey, E. [2007]. "Not by Productivity Alone: How Visibility and Specialization Contribute to Academic Earnings.” American Sociological Review 72(4):533-61.

Lissoni Francesco, Jacques Mairesse, Fabio Montobbio and Michele Pezzoni. [2011]. “Scientific Productivity and Academic Promotion: A Study on French and Italian Physicists". Industrial and Corporate Change, 20 (1): 253-294.

Long, J. Scott, Paul D. Allison, and Robert McGinnis. [1993]. "Rank Advancement in Academic Careers: Sex Differences and the Effects of Productivity.” American Sociological Review 58(5):703-722.

Mairesse Jacques and Michele Pezzoni. [2015]. "Does Gender Affect Scientific Productivity? A Critical Review of the Empirical Evidence and a Panel Data Econometric Analysis for French Physicists”. Revue Economique, 66(1), p.65-113.

Mairesse, Jacques, Michele Pezzoni, and Fabiana Visentin. [2019]. "Impact of Family Characteristics on the Gender Publication Gap: Evidence for Physicists in France.” Interdisciplinary Science Reviews 18.

Manchester, Colleen Flaherty, Lisa M. Leslie, and Amit Kramer. [2010]. “Stop the Clock Policies and Career Success in Academia.” American Economic Review 100(2):219-23.

Mason, Mary Ann, Nicholas H. Wolfinger, and Marc Goulden. [2013]. Do Babies Matter?: Gender and Family in the Ivory Tower. Rutgers University Press.

McDowell, John M., Larry D. Singell, and James P. Ziliak. [1999]. "Cracks in the Glass Ceiling: Gender and Promotion in the Economics Profession.” American Economic Review 89(2):392-96.

Merton, Robert K. [1942]. The Sociology of Science: Theoretical and Empirical Investigations. University of Chicago Press. 
Nature Editorial. [2013]. "Science for All : Nature News \& Comment."

Pepin, Anne, Natalia Vacherand, and Andreea Dumitrascu. [2019]."Femmes en physique Actions de la mission pour la place des femmes au CNRS_JMC13_Montpellier 30 août 2012.” (www.sfpnet.fr > uploads > tinymce > JMC13_AnnePepin).

Pezzoni Michele, Jacques Mairesse, Paula Stephan and Julia Lane. [2016]. "Gender and the Publication Output of Graduate Students: A Case Study”. PLOS ONE: 11(1) -12 pages.

Rudd, Elizabeth, Emory Morrison, Renate Sadrozinski, Maresi Nerad, and Joseph Cerny. [2008]. "Equality and Illusion: Gender and Tenure in Art History Careers.” Journal of Marriage and Family 70(1):228-38.

Sabatier, Mareva. [2010]. "Do Female Researchers Face a Glass Ceiling in France? A Hazard Model of Promotions.” Applied Economics 42(16):2053-62.

Sarsons, Heather. [2017]. "Recognition for Group Work: Gender Differences in Academia.” American Economic Review 107(5):141-45.

Stewart, Penni, Michael Ornstein, and Janice Drakich. [2009]. "Gender and Promotion at Canadian Universities." Canadian Review of Sociology/Revue Canadienne de Sociologie 46(1):59-85.

Sonnert, G., Holton G.J. [1995]. ““'Who Succeeds in Science? The Gender Dimension”.” New Brunswick (N.J.): Rutgers University Press.

Weisshaar, Katherine. [2017]. "Publish and Perish? An Assessment of Gender Gaps in Promotion to Tenure in Academia.” Social Forces 96(2):529-60.

Wolfinger, Nicholas H., Mary Ann Mason, and Marc Goulden. [2008]. "Problems in the Pipeline: Gender, Marriage, and Fertility in the Ivory Tower.” The Journal of Higher Education 79(4):388-405.

Wooldridge, Jeffrey M. [2002]. Econometric Analysis of Cross Section and Panel Data. The MIT Press. 


\section{Appendix A}

Table A1: Differences between available characteristics for both respondents and non-respondents to the online survey of INP physicists.

\begin{tabular}{|c|c|c|c|}
\hline & $\begin{array}{c}\text { Respondents (604) } \\
\text { Mean variable }\end{array}$ & $\begin{array}{l}\text { Non-respondents (481) } \\
\text { Mean variable }\end{array}$ & P-value \\
\hline Year of birth & 1969.96 & 1967.25 & 0.00 \\
\hline Female & 0.23 & 0.14 & 0.00 \\
\hline Section 2: Physical theories & 0.19 & 0.24 & 0.02 \\
\hline $\begin{array}{l}\text { Section 3: Condensed matter physics (structures and electronic } \\
\text { properties) }\end{array}$ & 0.24 & 0.27 & 0.20 \\
\hline $\begin{array}{l}\text { Section 4: Atoms and Molecules, Optics and Lasers, Hot } \\
\text { Plasma Physics }\end{array}$ & 0.29 & 0.25 & 0.09 \\
\hline $\begin{array}{l}\text { Section 5: Condensed matter physics (organizations and } \\
\text { dynamics) }\end{array}$ & 0.28 & 0.24 & 0.09 \\
\hline Junior researcher (Second class) & 0.07 & 0.06 & 0.43 \\
\hline Junior researcher (First class) & 0.47 & 0.45 & 0.57 \\
\hline Senior researcher (Second class) & 0.27 & 0.27 & 0.87 \\
\hline Senior researcher (First class) & 0.16 & 0.18 & 0.41 \\
\hline Senior researcher (Exceptional) & 0.02 & 0.03 & 0.11 \\
\hline
\end{tabular}




\section{Appendix B: Robustness checks.}

\section{Appendix B1}

In this appendix, we estimate a parametric proportional hazard model, assuming a Weibull distribution of the baseline hazard function. Equation B1-1 shows a parametric proportional hazard model where $t$ is the time passed since when the scientist is at risk of promotion to $\mathrm{DR}, h_{0}(t)$ is a baseline hazard function, $x_{1}$ is the vector of time-invariant covariates, $x_{2}$ is the vector of timevariant covariates, $\beta_{1}$ and $\beta_{2}$ are the vectors of coefficients to be estimated. Assuming that our baseline hazard function has a Weibull distribution $h_{0}(t)=p t^{p-1}$ Equation B1-1 writes as follow:

$$
h_{i}(t)=h_{0}(t) e^{\left(\beta_{1} x_{1, i}+\beta_{2} x_{2, i}(t-1)\right)}=p t^{p-1} e^{\left(\beta_{1} x_{1, i}+\beta_{2} x_{2, i}(t-1)\right)} \quad \text { Equation B1 }
$$

Table B1-1 reports the estimates of the models for the overall sample of scientists. Table B1-2 reports the model estimated including all the interactions between the dummy variable Female and all the other covariates. In both tables, the estimates are full maximum-likelihood. We find substantial coherence with the results showed in Tables 3 and 4 in the main text. According to our estimate of the Weibull parameter $\hat{p}$, we find that the rate of promotion increases with time. For instance, when we consider the estimates in Column 4 Table B1-1, the rate of promotion after four years is $43 \%$ higher than the rate of promotion after three years $\left((4 / 3)^{2.244-1}\right)$.

In Figure B1-1 and Figure B1-2, relying on Column 4 (Table B1-1) estimates, we report the fitted survival and hazard functions for a female and male scientist with an overall average value for all the covariates other than Female. We also report the 95\% confidence intervals of the fitted functions showing that the graph is coherent with the non-significance of the coefficient of the variable Female estimated in Column 4.

The results presented in Tables B1-1 and B1-2 are consistent with the ones reported in Tables 3 and 4 in the main text. 
Table B1-1: Event history analysis for promotion to DR using maximum likelihood estimations of the parametric model assuming the Weibull functional form of the baseline hazard $\left(h_{0}(t)=\right.$ $\left.p t^{p-1}\right)$.

\begin{tabular}{|c|c|c|c|c|}
\hline & $\begin{array}{c}\text { (1) } \\
\text { All } \\
\text { Hazard ratio }\end{array}$ & $\begin{array}{c}(2) \\
\text { All } \\
\text { Hazard ratio }\end{array}$ & $\begin{array}{c}\text { (3) } \\
\text { All } \\
\text { Hazard ratio }\end{array}$ & $\begin{array}{c}(4) \\
\text { All } \\
\text { Hazard ratio }\end{array}$ \\
\hline Female & $\begin{array}{l}0.569 * * * \\
(0.100)\end{array}$ & $\begin{array}{c}0.557 * * * \\
(0.110)\end{array}$ & $\begin{array}{c}0.782 \\
(0.139)\end{array}$ & $\begin{array}{c}0.778 \\
(0.151)\end{array}$ \\
\hline Cumulated number of articles in $\mathrm{t}-1$ & & & $\begin{array}{l}1.019 * * * \\
(0.00431)\end{array}$ & $\begin{array}{l}1.027 * * * \\
(0.00487)\end{array}$ \\
\hline Cumulated number of conference papers in $\mathrm{t}-1$ & & & $\begin{array}{c}1.002 \\
(0.00674)\end{array}$ & $\begin{array}{c}0.998 \\
(0.00741)\end{array}$ \\
\hline Average number of citations in $\mathrm{t}-1$ & & & $\begin{array}{l}1.048^{* *} \\
(0.0213)\end{array}$ & $\begin{array}{l}1.069 * * * \\
(0.0245)\end{array}$ \\
\hline At least one EPO patent in $\mathrm{t}-1$ & & & & $\begin{array}{l}1.208 \\
(0.299)\end{array}$ \\
\hline Cumulated number of collaborators in t-1 & & & & $\begin{array}{c}0.992 * * \\
(0.00362)\end{array}$ \\
\hline Cumulated number Ph.D. theses supervised in t-1 & & & & $\begin{array}{l}1.233 * * * \\
(0.0855)\end{array}$ \\
\hline Cumulated years as head of a research team in t-1 & & & & $\begin{array}{l}1.088 * * * \\
(0.0226)\end{array}$ \\
\hline $\begin{array}{l}\text { Cumulated years with other research } \\
\text { responsibilities in t-1 }\end{array}$ & & & & 0.973 \\
\hline At least one ANR or EU grant in t-1 & & & & $\begin{array}{c}(0.0305) \\
0.808 \\
(0.279)\end{array}$ \\
\hline Family size in $\mathrm{t}-1$ & & $\begin{array}{l}1.149 * * \\
(0.0659)\end{array}$ & & $\begin{array}{l}1.132^{*} \\
(0.0720)\end{array}$ \\
\hline One child less than 3 years old & & $\begin{array}{c}0.860 \\
(0.152)\end{array}$ & & $\begin{array}{c}0.820 \\
(0.146)\end{array}$ \\
\hline Age at $\mathrm{CR}$ & & $\begin{array}{c}0.983 \\
(0.0385)\end{array}$ & & $\begin{array}{c}1.003 \\
(0.0385)\end{array}$ \\
\hline Ph.D. from a Paris university ${ }^{\mathrm{a}}$ & & $\begin{array}{l}0.679 * \\
(0.143)\end{array}$ & & $\begin{array}{l}0.680^{*} \\
(0.152)\end{array}$ \\
\hline Ph.D. from a French university ${ }^{a}$ & & $\begin{array}{c}0.888 \\
(0.168)\end{array}$ & & $\begin{array}{c}0.801 \\
(0.174)\end{array}$ \\
\hline Ph.D. graduation year 2001-2017b & & $\begin{array}{c}0.735 \\
(0.243)\end{array}$ & & $\begin{array}{c}0.775 \\
(0.275)\end{array}$ \\
\hline Ph.D. graduation year $1991-2000^{\mathrm{b}}$ & & $\begin{array}{l}1.196 \\
(0.195)\end{array}$ & & $\begin{array}{l}1.100 \\
(0.194)\end{array}$ \\
\hline Recruited as CR1 & & $\begin{array}{l}1.693^{* *} \\
(0.401)\end{array}$ & & $\begin{array}{l}1.621^{* *} \\
(0.387)\end{array}$ \\
\hline Gender parity initiative (MPPF) & & $\begin{array}{l}1.119 \\
(0.242)\end{array}$ & & $\begin{array}{c}0.835 \\
(0.208)\end{array}$ \\
\hline Section dummies & No & Yes & No & Yes \\
\hline Constant & $\begin{array}{c}0.000335 * * * \\
(0.000110)\end{array}$ & $\begin{array}{c}0.000525 * * * \\
(0.000644)\end{array}$ & $\begin{array}{c}0.000303 * * * \\
(0.000107)\end{array}$ & $\begin{array}{c}0.000492^{* * *} \\
(0.000609)\end{array}$ \\
\hline Log-likelihood & -313.747 & -290.369 & -280.568 & -226.885 \\
\hline Weibull parameter $\hat{p}$ & 2.683 & 2.665 & 2.434 & 2.244 \\
\hline Number of scientists & 604 & 604 & 604 & 604 \\
\hline Number of scientists not promoted (censored) & 328 & 328 & 328 & 328 \\
\hline Observations & 7,805 & 7,805 & 7,805 & 7,805 \\
\hline
\end{tabular}

Note: A coefficient lower than one is associated with a reduction of the promotion hazard rate, while a coefficient greater than one

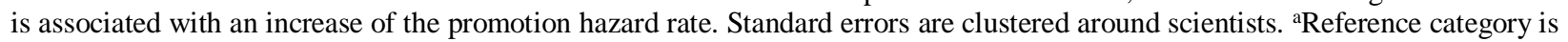

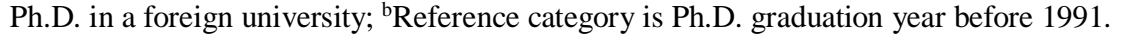


Table B1-2: Event history analysis for promotion to DR using maximum likelihood estimations of the parametric model assuming the Weibull functional form of the baseline hazard $\left(h_{0}(t)=\right.$ $p t^{p-1}$ ). The model includes all interactions between the Female variable and the other regressors. Column 1 reports Hazard ratios, while Column 2 reports raw coefficients.

\begin{tabular}{|c|c|c|}
\hline & $\begin{array}{c}\text { (1) } \\
\text { Hazard ratio }\end{array}$ & $\begin{array}{c}(2) \\
\text { Raw coefficients }\end{array}$ \\
\hline Female & $\begin{array}{c}0.343 \\
(1.295)\end{array}$ & $\begin{array}{c}-1.070 \\
(3.778)\end{array}$ \\
\hline Cumulated number of articles in t-1 & $\begin{array}{l}1.029 * * * \\
(0.00581)\end{array}$ & $\begin{array}{l}0.0288 * * * \\
(0.00564)\end{array}$ \\
\hline Female ${ }^{*}$ Cumulated number of articles in $t-1$ & $\begin{array}{c}1.010 \\
(0.00902)\end{array}$ & $\begin{array}{c}0.00980 \\
(0.00893)\end{array}$ \\
\hline Cumulated number of conference papers in t-1 & $\begin{array}{c}0.998 \\
(0.00827)\end{array}$ & $\begin{array}{c}-0.00196 \\
(0.00829)\end{array}$ \\
\hline Female*Cumulated number of conference papers in $t-1$ & $\begin{array}{c}0.990 \\
(0.0322)\end{array}$ & $\begin{array}{l}-0.00987 \\
(0.0325)\end{array}$ \\
\hline Average number of citations in $\mathrm{t}-1$ & $\begin{array}{l}1.059 * * \\
(0.0241)\end{array}$ & $\begin{array}{l}0.0573 * * \\
(0.0228)\end{array}$ \\
\hline Female*Average number of citations in $t-1$ & $\begin{array}{c}1.158 \\
(0.116)\end{array}$ & $\begin{array}{c}0.147 \\
(0.100)\end{array}$ \\
\hline At least one EPO patent in $\mathrm{t}-1$ & $\begin{array}{c}1.413 \\
(0.371)\end{array}$ & $\begin{array}{c}0.346 \\
(0.263)\end{array}$ \\
\hline Female*At least one EPO patent in $t-1$ & $\begin{array}{c}0.324 \\
(0.228)\end{array}$ & $\begin{array}{l}-1.128 \\
(0.705)\end{array}$ \\
\hline Cumulated number of collaborators in t-1 & $\begin{array}{c}0.990 * * \\
(0.00425)\end{array}$ & $\begin{array}{l}-0.0102^{* *} \\
(0.00430)\end{array}$ \\
\hline Female ${ }^{*}$ Cumulated number of collaborators in $t-1$ & $\begin{array}{c}0.999 \\
(0.0101)\end{array}$ & $\begin{array}{l}-0.00134 \\
(0.0101)\end{array}$ \\
\hline Cumulated number Ph.D. theses supervised in t-1 & $\begin{array}{l}1.299 * * * \\
(0.108)\end{array}$ & $\begin{array}{l}0.261^{* * * *} \\
(0.0834)\end{array}$ \\
\hline Female*Cumulated number Ph.D. theses supervised in $t-1$ & $\begin{array}{c}0.938 \\
(0.189)\end{array}$ & $\begin{array}{l}-0.0640 \\
(0.202)\end{array}$ \\
\hline Cumulated years as head of a research team in t-1 & $\begin{array}{l}1.073 * * * \\
(0.0289)\end{array}$ & $\begin{array}{c}0.0707 * * * \\
(0.0269)\end{array}$ \\
\hline Female ${ }^{*}$ Cumulated years as head of a research team in $t-1$ & $\begin{array}{c}1.057 \\
(0.0454)\end{array}$ & $\begin{array}{c}0.0557 \\
(0.0429)\end{array}$ \\
\hline Cumulated years with other research responsibilities in t-1 & $\begin{array}{c}0.968 \\
(0.0335)\end{array}$ & $\begin{array}{l}-0.0323 \\
(0.0346)\end{array}$ \\
\hline Female ${ }^{*}$ Cumulated years with other research responsibilities in $t-1$ & $\begin{array}{c}1.020 \\
(0.108)\end{array}$ & $\begin{array}{l}0.0198 \\
(0.106)\end{array}$ \\
\hline At least one ANR or EU grant in $\mathrm{t}-1$ & $\begin{array}{c}0.581 \\
(0.234)\end{array}$ & $\begin{array}{l}-0.544 \\
(0.403)\end{array}$ \\
\hline Female*At least one ANR or EU grant in $t-1$ & $\begin{array}{c}6.020 * * * \\
(4.184)\end{array}$ & $\begin{array}{c}1.795 * * * \\
(0.695)\end{array}$ \\
\hline Family size in $\mathrm{t}-1$ & $\begin{array}{c}1.138^{*} \\
(0.0815)\end{array}$ & $\begin{array}{c}0.129 * \\
(0.0716)\end{array}$ \\
\hline Female $*$ Family size in $t-1$ & $\begin{array}{c}0.940 \\
(0.175)\end{array}$ & $\begin{array}{l}-0.0616 \\
(0.186)\end{array}$ \\
\hline One child less than 3 years old & $\begin{array}{c}0.848 \\
(0.164)\end{array}$ & $\begin{array}{l}-0.165 \\
(0.193)\end{array}$ \\
\hline Female* One child less than 3 years old & $\begin{array}{c}0.916 \\
(0.435)\end{array}$ & $\begin{array}{l}-0.0879 \\
(0.474)\end{array}$ \\
\hline Age at CR & $\begin{array}{c}1.000 \\
(0.0400)\end{array}$ & $\begin{array}{l}-5.82 \mathrm{e}-05 \\
(0.0401)\end{array}$ \\
\hline Female*Age at CR & $\begin{array}{c}1.025 \\
(0.127)\end{array}$ & $\begin{array}{l}0.0245 \\
(0.124)\end{array}$ \\
\hline Ph.D. from a Paris university ${ }^{\mathrm{a}}$ & $\begin{array}{c}0.939 \\
(0.260)\end{array}$ & $\begin{array}{r}-0.0627 \\
(0.277)\end{array}$ \\
\hline Female*Ph.D. from a Paris university & $\begin{array}{l}0.326^{*} \\
(0.207)\end{array}$ & $\begin{array}{l}-1.120 * \\
(0.635)\end{array}$ \\
\hline Ph.D. from a French university ${ }^{\mathrm{a}}$ & $\begin{array}{c}0.980 \\
(0.276)\end{array}$ & $\begin{array}{r}-0.0202 \\
(0.282)\end{array}$ \\
\hline Female*Ph.D. from a French university & $\begin{array}{c}0.509 \\
(0.231)\end{array}$ & $\begin{array}{c}-0.676 \\
(0.455)\end{array}$ \\
\hline Ph.D. graduation year 2001-2017 & $\begin{array}{c}0.733 \\
(0.280)\end{array}$ & $\begin{array}{c}-0.310 \\
(0.381)\end{array}$ \\
\hline
\end{tabular}




\begin{tabular}{lcc} 
Female*Ph.D. graduation year 2001-2017 $^{*}$ & 1.390 & 0.329 \\
& $(1.304)$ & $(0.938)$ \\
Ph.D. graduation year 1991-2000 ${ }^{\mathrm{b}}$ & 1.099 & 0.0942 \\
& $(0.217)$ & $(0.198)$ \\
Female*Ph.D. graduation year 1991-2000 $^{*}$ & 1.051 & 0.0502 \\
& $(0.503)$ & $(0.478)$ \\
Recruited as CR1 & $1.787 * *$ & $0.580^{* *}$ \\
& $(0.481)$ & $(0.269)$ \\
Female*Recruited as CR1 & 1.181 & 0.167 \\
& $(0.719)$ & $(0.608)$ \\
Gender parity initiative (MPPF) & 0.854 & -0.158 \\
& $(0.235)$ & $(0.275)$ \\
Female*Gender parity initiative (MPPF) & 0.944 & -0.0575 \\
& $(0.622)$ & $(0.659)$ \\
Constant & $0.000427 * * *$ & $-7.758 * * *$ \\
& $(0.000549)$ & $(1.285)$ \\
Section dummies & Yes & Yes \\
Section dummies interacted with Female & Yes & Yes \\
Log-likelihood & -215.88 & -215.88 \\
Weibull parameter $\hat{p}$ & 2.289 & 2.289 \\
Number of scientists & 604 & 604 \\
Number of scientists not promoted (censored) & 328 & 328 \\
Observations & 7,805 & 7,805 \\
\hline
\end{tabular}

Note: In Column 1, a coefficient lower than one is associated with a reduction of the hazard rate of promotion, while a coefficient greater than one is associated with an increase of the hazard rate of promotion. Column 2 reports the raw coefficients useful to

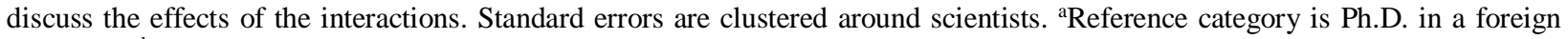
university; ${ }^{b}$ Reference category is Ph.D. graduation year before 1991. 
Figure B1-1: Weibull survival distribution by gender fitted from estimates in Table B1-1, column 4.

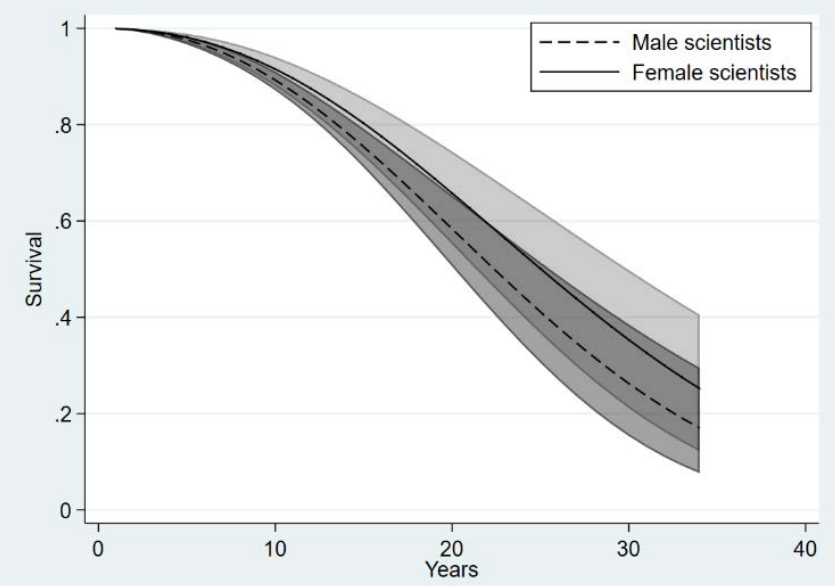

Note: The analysis time corresponds to the number of years elapsed from the recruitment as CR to the promotion to DR.

Figure B1-2: Weibull hazard distribution by gender fitted from estimates in Table B1-1, column 4.

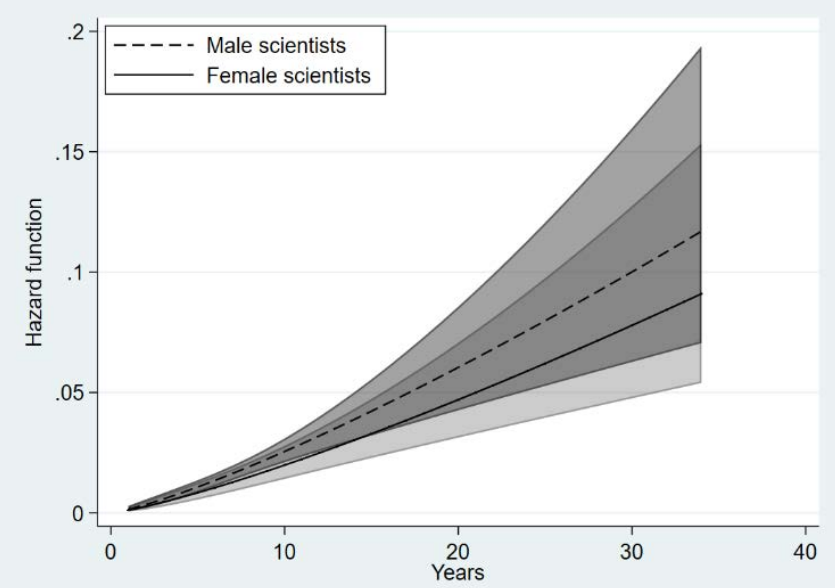

Note: The analysis time corresponds to the number of years elapsed from the recruitment as CR to the promotion to DR. 


\section{Appendix B2}

In this appendix, we run separated regressions considering the promotion to intermediate positions. At CNRS, the career step CR has two intermediate career steps: CR2 and CR1. Similarly, DR has two steps: DR2 and DR1 ${ }^{16}$. In Tables B2-1 and B2-2, we estimated a Cox regression model for the promotion from CR1 to DR2. The results are consistent with the ones reported in Tables 3 and 4, except for the variable Family size in $t-1$ that loses its significance for males (Table B2-2). In Tables B2-3 and B2-4, we estimated a Cox regression model for the promotion from DR2 to DR1. In this case, we found different results from Tables 3 and 4 . The Female variable is no longer significant both with and without productivity and family controls (Table B2-3, Columns 1, 2, 3, and 4). Consistently with the models estimated in Table 4, Table B2-4 shows that publication quality plays a positive and significant role for males increasing their rate of promotion but is no longer significant for females (although the difference between the two coefficients is statistically significant). The cumulated number of articles coefficient is significant for male but no longer significant for female researchers (although the difference between the two coefficients is statistically significant). Interestingly, when we consider the promotion from DR2 to DR1, having ANR or EU grants and the size of the family boost significantly the female scientists' rate of promotion with respect to their male counterparts.

\footnotetext{
${ }^{16}$ To better understand the promotion dynamics at CNRS, we interviewed a member of the National Committee of Scientific Research (CoNRS). CoNRS is an independent organisation that helps CNRS to define the scientific policy of CNRS in terms of recruitment and career advancements of researchers. The CoNRS member confirmed that the most important and challenging career steps for a CNRS researcher are the promotion from CR1 to DR2 and from DR2 to DR1. The promotion from CR2 to CR1 depends mostly on seniority.
} 
Table B2-1: Event history analysis using Cox’s partial likelihood estimator for the proportional hazard model. Promotion from CR1 to DR2.

\begin{tabular}{|c|c|c|c|c|}
\hline & $\begin{array}{c}\text { (1) } \\
\text { All } \\
\text { Hazard ratio }\end{array}$ & $\begin{array}{c}\text { (2) } \\
\text { All } \\
\text { Hazard ratio }\end{array}$ & $\begin{array}{c}\text { (3) } \\
\text { All } \\
\text { Hazard ratio }\end{array}$ & $\begin{array}{c}\text { (4) } \\
\text { All } \\
\text { Hazard ratio } \\
\end{array}$ \\
\hline Female & $\begin{array}{c}0.601 * * * \\
(0.0850)\end{array}$ & $\begin{array}{c}0.632 * * * \\
(0.0965)\end{array}$ & $\begin{array}{c}0.817 \\
(0.119)\end{array}$ & $\begin{array}{c}0.875 \\
(0.139)\end{array}$ \\
\hline Cumulated number of articles in $\mathrm{t}-1$ & & & $\begin{array}{l}1.020 * * * \\
(0.00254)\end{array}$ & $\begin{array}{l}1.026 * * * \\
(0.00438)\end{array}$ \\
\hline Cumulated number of conference papers in $\mathrm{t}-1$ & & & $\begin{array}{c}0.999 \\
(0.00494)\end{array}$ & $\begin{array}{c}0.997 \\
(0.00640)\end{array}$ \\
\hline Average number of citations in $\mathrm{t}-1$ & & & $\begin{array}{l}1.049 * * \\
(0.0233)\end{array}$ & $\begin{array}{l}1.065^{* * *} \\
(0.0251)\end{array}$ \\
\hline At least one EPO patent in $\mathrm{t}-1$ & & & & $\begin{array}{c}1.115 \\
(0.251)\end{array}$ \\
\hline Cumulated number of collaborators in $\mathrm{t}-1$ & & & & $\begin{array}{c}0.995 \\
(0.00332)\end{array}$ \\
\hline Cumulated number Ph.D. theses supervised in $\mathrm{t}-1$ & & & & $\begin{array}{l}1.227 * * * \\
(0.0797)\end{array}$ \\
\hline Cumulated years as head of a research team in $\mathrm{t}-1$ & & & & $\begin{array}{l}1.075^{* * *} \\
(0.0183)\end{array}$ \\
\hline Cumulated years with other research responsibilities in t-1 & & & & $\begin{array}{c}0.975 \\
(0.0273)\end{array}$ \\
\hline At least one ANR or EU grant in $\mathrm{t}-1$ & & & & $\begin{array}{c}0.662 \\
(0.223)\end{array}$ \\
\hline Family size in $\mathrm{t}-1$ & & $\begin{array}{c}1.093^{*} \\
(0.0522)\end{array}$ & & $\begin{array}{c}1.067 \\
(0.0550)\end{array}$ \\
\hline One child less than 3 years old & & $\begin{array}{c}0.845 \\
(0.140)\end{array}$ & & $\begin{array}{c}0.777 \\
(0.129)\end{array}$ \\
\hline Age at CR & & $\begin{array}{c}1.001 \\
(0.0309)\end{array}$ & & $\begin{array}{c}1.018 \\
(0.0304)\end{array}$ \\
\hline Ph.D. from a Paris university ${ }^{a}$ & & $\begin{array}{c}0.965 \\
(0.160)\end{array}$ & & $\begin{array}{c}0.917 \\
(0.161)\end{array}$ \\
\hline Ph.D. from a French university ${ }^{a}$ & & $\begin{array}{c}1.041 \\
(0.159)\end{array}$ & & $\begin{array}{c}0.857 \\
(0.144)\end{array}$ \\
\hline Ph.D. graduation year 2001-2017b & & $\begin{array}{c}0.800 \\
(0.262)\end{array}$ & & $\begin{array}{c}0.930 \\
(0.319)\end{array}$ \\
\hline Ph.D. graduation year $1991-2000^{\mathrm{b}}$ & & $\begin{array}{c}0.910 \\
(0.129)\end{array}$ & & $\begin{array}{c}0.861 \\
(0.133)\end{array}$ \\
\hline Recruited as CR1 & & $\begin{array}{c}1.186 \\
(0.212)\end{array}$ & & $\begin{array}{c}1.300 \\
(0.234)\end{array}$ \\
\hline Gender parity initiative (MPPF) & & $\begin{array}{c}1.319 \\
(0.289)\end{array}$ & & $\begin{array}{c}0.931 \\
(0.234)\end{array}$ \\
\hline Section dummies & No & Yes & No & Yes \\
\hline Pseudo R squared & 0.004 & 0.012 & 0.026 & 0.053 \\
\hline Number of scientists & 559 & 559 & 559 & 559 \\
\hline Number of scientists not promoted (censored) & 283 & 283 & 283 & 283 \\
\hline Observations & 6,041 & 6,041 & 6,041 & 6,041 \\
\hline
\end{tabular}

Note: A coefficient lower than one is associated with a reduction of the hazard rate of promotion, while a coefficient greater than one is associated with an increase of the hazard rate of promotion. Standard errors are clustered around scientists. ${ }^{\text {aneference }}$ category is Ph.D. in a foreign university; ${ }^{b}$ Reference category is Ph.D. graduation year before 1991. 
Table B2-2: Event history analysis using Cox’s partial likelihood estimator for the proportional hazard model. Promotion from CR1 to DR2. The model includes interactions with the Female variable.

\begin{tabular}{|c|c|c|}
\hline & $\begin{array}{c}\text { (1) } \\
\text { Hazard ratio }\end{array}$ & $\begin{array}{c}\text { (2) } \\
\text { Raw coefficients }\end{array}$ \\
\hline Female & $\begin{array}{c}0.302 \\
(1.049)\end{array}$ & $\begin{array}{l}-1.197 \\
(3.471)\end{array}$ \\
\hline Cumulated number of articles in $\mathrm{t}-1$ & $\begin{array}{l}1.030 * * * \\
(0.00513)\end{array}$ & $\begin{array}{l}0.0292 * * * \\
(0.00498)\end{array}$ \\
\hline Female $*$ Cumulated number of articles in $t-1$ & $\begin{array}{c}0.999 \\
(0.00889)\end{array}$ & $\begin{array}{l}-0.00104 \\
(0.00890)\end{array}$ \\
\hline Cumulated number of conference papers in $\mathrm{t}-1$ & $\begin{array}{c}0.996 \\
(0.00687)\end{array}$ & $\begin{array}{l}-0.00354 \\
(0.00690)\end{array}$ \\
\hline Female $*$ Cumulated number of conference papers in $t-1$ & $\begin{array}{c}1.005 \\
(0.0295)\end{array}$ & $\begin{array}{l}0.00468 \\
(0.0293)\end{array}$ \\
\hline Average number of citations in $\mathrm{t}-1$ & $\begin{array}{l}1.056^{* *} \\
(0.0248)\end{array}$ & $\begin{array}{l}0.0546 * * \\
(0.0234)\end{array}$ \\
\hline Female $*$ Average number of citations in $t-1$ & $\begin{array}{l}1.154 \\
(0.131)\end{array}$ & $\begin{array}{c}0.143 \\
(0.114)\end{array}$ \\
\hline At least one EPO patent in $\mathrm{t}-1$ & $\begin{array}{l}1.296 \\
(0.295)\end{array}$ & $\begin{array}{c}0.260 \\
(0.228)\end{array}$ \\
\hline Female $*$ At least one EPO patent in $t-1$ & $\begin{array}{c}0.395 \\
(0.259)\end{array}$ & $\begin{array}{l}-0.928 \\
(0.654)\end{array}$ \\
\hline Cumulated number of collaborators in $\mathrm{t}-1$ & $\begin{array}{c}0.991^{* *} \\
(0.00371)\end{array}$ & $\begin{array}{c}-0.00868 * * \\
(0.00375)\end{array}$ \\
\hline Female $*$ Cumulated number of collaborators in $t-1$ & $\begin{array}{c}1.003 \\
(0.0104)\end{array}$ & $\begin{array}{l}0.00332 \\
(0.0104)\end{array}$ \\
\hline Cumulated number Ph.D. theses supervised in $\mathrm{t}-1$ & $\begin{array}{l}1.271 * * * \\
(0.0931)\end{array}$ & $\begin{array}{l}0.240 * * * \\
(0.0733)\end{array}$ \\
\hline Female*Cumulated number Ph.D. theses supervised in $t-1$ & $\begin{array}{l}1.044 \\
(0.183)\end{array}$ & $\begin{array}{l}0.0434 \\
(0.175)\end{array}$ \\
\hline Cumulated years as head of a research team in t-1 & $\begin{array}{l}1.056^{* *} \\
(0.0223)\end{array}$ & $\begin{array}{l}0.0541 * * \\
(0.0211)\end{array}$ \\
\hline Female ${ }^{*}$ Cumulated years as head of a research team in $t-1$ & $\begin{array}{l}1.070^{*} \\
(0.0432)\end{array}$ & $\begin{array}{l}0.0677^{*} \\
(0.0404)\end{array}$ \\
\hline Cumulated years with other research responsibilities in $\mathrm{t}-1$ & $\begin{array}{c}0.971 \\
(0.0287)\end{array}$ & $\begin{array}{l}-0.0296 \\
(0.0296)\end{array}$ \\
\hline Female*Cumulated years with other research responsibilities in $t-1$ & $\begin{array}{c}1.055 \\
(0.118)\end{array}$ & $\begin{array}{l}0.0532 \\
(0.112)\end{array}$ \\
\hline At least one ANR or EU grant in $\mathrm{t}-1$ & $\begin{array}{l}0.474^{*} \\
(0.192)\end{array}$ & $\begin{array}{l}-0.747^{*} \\
(0.406)\end{array}$ \\
\hline Female*At least one ANR or EU grant in $t-1$ & $\begin{array}{l}5.530 * * \\
(3.970)\end{array}$ & $\begin{array}{l}1.710^{* *} \\
(0.718)\end{array}$ \\
\hline Family size in $\mathrm{t}-1$ & $\begin{array}{c}1.091 \\
(0.0614)\end{array}$ & $\begin{array}{c}0.0873 \\
(0.0562)\end{array}$ \\
\hline Female $*$ Family size in $t-1$ & $\begin{array}{l}0.893 \\
(0.148)\end{array}$ & $\begin{array}{l}-0.113 \\
(0.166)\end{array}$ \\
\hline One child less than 3 years old & $\begin{array}{c}0.782 \\
(0.138)\end{array}$ & $\begin{array}{l}-0.246 \\
(0.176)\end{array}$ \\
\hline Female* One child less than 3 years old & $\begin{array}{l}1.068 \\
(0.482)\end{array}$ & $\begin{array}{l}0.0662 \\
(0.451)\end{array}$ \\
\hline Age at CR & $\begin{array}{c}1.015 \\
(0.0329)\end{array}$ & $\begin{array}{c}0.0150 \\
(0.0324)\end{array}$ \\
\hline Female*Age at $C R$ & $\begin{array}{l}1.037 \\
(0.117)\end{array}$ & $\begin{array}{l}0.0364 \\
(0.113)\end{array}$ \\
\hline Ph.D. from a Paris university ${ }^{\mathrm{a}}$ & $\begin{array}{l}1.175 \\
(0.252)\end{array}$ & $\begin{array}{c}0.162 \\
(0.214)\end{array}$ \\
\hline Female*Ph.D. from a Paris university & $\begin{array}{l}0.430^{*} \\
(0.216)\end{array}$ & $\begin{array}{l}-0.845^{*} \\
(0.502)\end{array}$ \\
\hline Ph.D. from a French university ${ }^{a}$ & $\begin{array}{c}0.998 \\
(0.211)\end{array}$ & $\begin{array}{c}-0.00171 \\
(0.211)\end{array}$ \\
\hline Female*Ph.D. from a French university & $\begin{array}{c}0.539 \\
(0.223)\end{array}$ & $\begin{array}{l}-0.618 \\
(0.414)\end{array}$ \\
\hline Ph.D. graduation year $2001-2017^{b}$ & $\begin{array}{c}0.886 \\
(0.329)\end{array}$ & $\begin{array}{l}-0.122 \\
(0.371)\end{array}$ \\
\hline Female*Ph.D. graduation year 2001-2017 & $\begin{array}{l}1.078 \\
(1.052)\end{array}$ & $\begin{array}{l}0.0751 \\
(0.976)\end{array}$ \\
\hline Ph.D. graduation year $1991-2000^{\mathrm{b}}$ & $\begin{array}{c}0.856 \\
(0.147)\end{array}$ & $\begin{array}{l}-0.155 \\
(0.172)\end{array}$ \\
\hline Female*Ph.D. graduation year 1991-2000 & $\begin{array}{c}0.963 \\
(0.411)\end{array}$ & $\begin{array}{l}-0.0377 \\
(0.427)\end{array}$ \\
\hline Recruited as CR1 & $\begin{array}{l}1.408^{*} \\
(0.278)\end{array}$ & $\begin{array}{l}0.342^{*} \\
(0.197)\end{array}$ \\
\hline Female*Recruited as CR1 & $\begin{array}{c}0.887 \\
(0.493)\end{array}$ & $\begin{array}{l}-0.120 \\
(0.556)\end{array}$ \\
\hline Gender parity initiative (MPPF) & $\begin{array}{c}0.943 \\
(0.263)\end{array}$ & $\begin{array}{c}-0.0589 \\
(0.279)\end{array}$ \\
\hline
\end{tabular}




$\begin{array}{cc}0.980 & -0.0203 \\ (0.624) & (0.637) \\ \text { Yes } & \text { Yes } \\ \text { Yes } & \text { Yes } \\ 0.060 & 0.060 \\ 559 & 559 \\ 238 & 238 \\ 6,041 & 6,041\end{array}$

Note: In Column 1, a coefficient lower than one is associated with a reduction of the hazard rate of promotion, while a coefficient greater than one is associated with an increase of the hazard rate of promotion. Column 2 reports the raw coefficients useful to

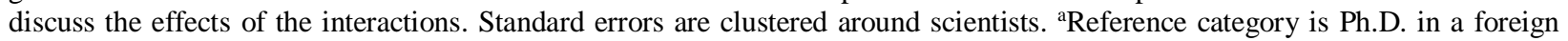
university; ${ }^{b}$ Reference category is Ph.D. graduation year before 1991. 
Table B2-3: Event history analysis using Cox's partial likelihood estimator for the proportional hazard model. Promotion from DR2 to DR1.

\begin{tabular}{|c|c|c|c|c|}
\hline & $\begin{array}{c}\text { (1) } \\
\text { All } \\
\text { Hazard ratio }\end{array}$ & $\begin{array}{c}\text { (2) } \\
\text { All } \\
\text { Hazard ratio }\end{array}$ & $\begin{array}{c}\text { (3) } \\
\text { All } \\
\text { Hazard ratio }\end{array}$ & $\begin{array}{c}\text { (4) } \\
\text { All } \\
\text { Hazard ratio }\end{array}$ \\
\hline Female & $\begin{array}{c}1.109 \\
(0.258)\end{array}$ & $\begin{array}{c}1.137 \\
(0.289)\end{array}$ & $\begin{array}{c}1.143 \\
(0.296)\end{array}$ & $\begin{array}{c}1.318 \\
(0.368)\end{array}$ \\
\hline Cumulated number of articles in $\mathrm{t}-1$ & & & $\begin{array}{c}1.003 \\
(0.00242)\end{array}$ & $\begin{array}{c}1.003 \\
(0.00446)\end{array}$ \\
\hline Cumulated number of conference papers in $\mathrm{t}-1$ & & & $\begin{array}{l}1.015^{* * *} \\
(0.00583)\end{array}$ & $\begin{array}{c}1.011^{*} \\
(0.00633)\end{array}$ \\
\hline Average number of citations in $\mathrm{t}-1$ & & & $\begin{array}{l}1.388 * * * \\
(0.0970)\end{array}$ & $\begin{array}{l}1.314 * * * \\
(0.0983)\end{array}$ \\
\hline At least one EPO patent in $\mathrm{t}-1$ & & & & $\begin{array}{c}1.476 \\
(0.384)\end{array}$ \\
\hline Cumulated number of collaborators in $\mathrm{t}-1$ & & & & $\begin{array}{c}0.999 \\
(0.00298)\end{array}$ \\
\hline Cumulated number Ph.D. theses supervised in $\mathrm{t}-1$ & & & & $\begin{array}{c}1.066 \\
(0.0580)\end{array}$ \\
\hline Cumulated years as head of a research team in $\mathrm{t}-1$ & & & & $\begin{array}{c}1.016 \\
(0.0160)\end{array}$ \\
\hline Cumulated years with other research responsibilities in t-1 & & & & $\begin{array}{l}1.050^{* *} \\
(0.0240)\end{array}$ \\
\hline At least one ANR or EU grant in $\mathrm{t}-1$ & & & & $\begin{array}{c}1.660 \\
(0.563)\end{array}$ \\
\hline Family size in $\mathrm{t}-1$ & & $\begin{array}{c}1.145^{*} \\
(0.0880)\end{array}$ & & $\begin{array}{c}1.069 \\
(0.0920)\end{array}$ \\
\hline One child less than 3 years old & & $\begin{array}{c}0.432 \\
(0.264)\end{array}$ & & $\begin{array}{c}0.483 \\
(0.275)\end{array}$ \\
\hline Age at CR & & $\begin{array}{c}0.996 \\
(0.0534)\end{array}$ & & $\begin{array}{c}1.037 \\
(0.0528)\end{array}$ \\
\hline Ph.D. from a Paris university ${ }^{a}$ & & $\begin{array}{c}1.462 \\
(0.339)\end{array}$ & & $\begin{array}{c}1.490 \\
(0.422)\end{array}$ \\
\hline Ph.D. from a French university ${ }^{a}$ & & $\begin{array}{c}1.058 \\
(0.247)\end{array}$ & & $\begin{array}{c}0.974 \\
(0.255)\end{array}$ \\
\hline Ph.D. graduation year $>=1991^{\mathrm{b}}$ & & $\begin{array}{c}2.322 * * * \\
(0.700)\end{array}$ & & $\begin{array}{c}1.369 \\
(0.470)\end{array}$ \\
\hline Recruited as CR1 & & $\begin{array}{c}0.809 \\
(0.191)\end{array}$ & & $\begin{array}{c}0.887 \\
(0.229)\end{array}$ \\
\hline Gender parity initiative (MPPF) & & $\begin{array}{c}0.675 \\
(0.573)\end{array}$ & & $\begin{array}{c}0.812 \\
(0.665)\end{array}$ \\
\hline Section dummies & No & Yes & No & Yes \\
\hline Pseudo R squared & 0.000 & 0.019 & 0.042 & 0.063 \\
\hline Number of scientists & 276 & 276 & 276 & 276 \\
\hline Number of scientists not promoted (censored) & 166 & 166 & 166 & 166 \\
\hline Observations & 2,531 & 2,531 & 2,531 & 2,531 \\
\hline
\end{tabular}

Note: A coefficient lower than one is associated with a reduction of the hazard rate of promotion, while a coefficient greater than one is associated with an increase of the hazard rate of promotion. Standard errors are clustered around scientists. ${ }^{\text {a Reference }}$ category is Ph.D. in a foreign university; ${ }^{b}$ We redefined the Ph.D. cohort dummies as follows: Ph.D. graduation year > = 1991 and Ph.D. graduation year < 1991. 
Table B2-4: Event history analysis using Cox’s partial likelihood estimator for the proportional hazard model. Promotion from DR2 to DR1. The model includes interactions with the Female variable.

\begin{tabular}{|c|c|c|}
\hline & $\begin{array}{c}\text { (1) } \\
\text { Hazard ratio }\end{array}$ & $\begin{array}{c}(2) \\
\text { Raw coefficients }\end{array}$ \\
\hline Female & $\begin{array}{c}1.366 \\
(5.726)\end{array}$ & $\begin{array}{c}0.312 \\
(4.191)\end{array}$ \\
\hline Cumulated number of articles in t-1 & $\begin{array}{c}1.012^{* *} \\
(0.00498)\end{array}$ & $\begin{array}{l}0.0117 * * \\
(0.00492)\end{array}$ \\
\hline Female $*$ Cumulated number of articles in $t-1$ & $\begin{array}{c}0.982^{*} \\
(0.0109)\end{array}$ & $\begin{array}{l}-0.0185^{*} \\
(0.0111)\end{array}$ \\
\hline Cumulated number of conference papers in $\mathrm{t}-1$ & $\begin{array}{l}1.019 * * \\
(0.00865)\end{array}$ & $\begin{array}{l}0.0190 * * \\
(0.00849)\end{array}$ \\
\hline Female ${ }^{*}$ Cumulated number of conference papers in $t-1$ & $\begin{array}{c}1.018 \\
(0.0264)\end{array}$ & $\begin{array}{c}0.0181 \\
(0.0259)\end{array}$ \\
\hline Average number of citations in $\mathrm{t}-1$ & $\begin{array}{c}1.526^{* * *} \\
(0.152)\end{array}$ & $\begin{array}{c}0.423 * * * \\
(0.0998)\end{array}$ \\
\hline Female $*$ Average number of citations in $t-1$ & $\begin{array}{l}0.468^{* *} \\
(0.143)\end{array}$ & $\begin{array}{c}-0.759 * * \\
(0.306)\end{array}$ \\
\hline At least one EPO patent in $\mathrm{t}-1$ & $\begin{array}{c}1.425 \\
(0.433)\end{array}$ & $\begin{array}{c}0.354 \\
(0.304)\end{array}$ \\
\hline Female $*$ At least one EPO patent in $t-1$ & $\begin{array}{l}130.4^{* *} \\
(274.3)\end{array}$ & $\begin{array}{l}4.870 * * \\
(2.104)\end{array}$ \\
\hline Cumulated number of collaborators in t-1 & $\begin{array}{c}0.995 \\
(0.00339)\end{array}$ & $\begin{array}{l}-0.00530 \\
(0.00341)\end{array}$ \\
\hline Female ${ }^{*}$ Cumulated number of collaborators in $t-1$ & $\begin{array}{c}1.001 \\
(0.0114)\end{array}$ & $\begin{array}{c}0.000836 \\
(0.0114)\end{array}$ \\
\hline Cumulated number Ph.D. theses supervised in t-1 & $\begin{array}{c}1.084 \\
(0.0631)\end{array}$ & $\begin{array}{c}0.0804 \\
(0.0582)\end{array}$ \\
\hline Female $*$ Cumulated number Ph.D. theses supervised in $t-1$ & $\begin{array}{l}0.855 \\
(0.151)\end{array}$ & $\begin{array}{l}-0.156 \\
(0.176)\end{array}$ \\
\hline Cumulated years as head of a research team in $\mathrm{t}-1$ & $\begin{array}{c}0.994 \\
(0.0184)\end{array}$ & $\begin{array}{l}-0.00620 \\
(0.0185)\end{array}$ \\
\hline Female ${ }^{*}$ Cumulated years as head of a research team in $t-1$ & $\begin{array}{c}1.078 \\
(0.0633)\end{array}$ & $\begin{array}{c}0.0750 \\
(0.0587)\end{array}$ \\
\hline Cumulated years with other research responsibilities in $\mathrm{t}-1$ & $\begin{array}{c}1.025 \\
(0.0284)\end{array}$ & $\begin{array}{c}0.0249 \\
(0.0277)\end{array}$ \\
\hline Female $*$ Cumulated years with other research responsibilities in $t-1$ & $\begin{array}{c}1.125 \\
(0.0945)\end{array}$ & $\begin{array}{c}0.118 \\
(0.0840)\end{array}$ \\
\hline At least one ANR or EU grant in $\mathrm{t}-1$ & $\begin{array}{c}0.886 \\
(0.516)\end{array}$ & $\begin{array}{l}-0.121 \\
(0.582)\end{array}$ \\
\hline Female*At least one ANR or EU grant in $t-1$ & $\begin{array}{l}3.574^{*} \\
(2.611)\end{array}$ & $\begin{array}{l}1.274^{*} \\
(0.731)\end{array}$ \\
\hline Family size in $\mathrm{t}-1$ & $\begin{array}{l}1.118 \\
(0.103)\end{array}$ & $\begin{array}{c}0.112 \\
(0.0925)\end{array}$ \\
\hline Female $*$ Family size in $t-1$ & $\begin{array}{l}1.697 * * \\
(0.449)\end{array}$ & $\begin{array}{c}0.529 * * \\
(0.265)\end{array}$ \\
\hline One child less than 3 years old & $\begin{array}{c}0.473 \\
(0.262)\end{array}$ & $\begin{array}{l}-0.748 \\
(0.554)\end{array}$ \\
\hline Female $*$ One child less than 3 years old & $\begin{array}{c}0 \\
(0)\end{array}$ & $\begin{array}{c}-39.64 \\
(0)\end{array}$ \\
\hline Age at $\mathrm{CR}$ & $\begin{array}{c}1.059 \\
(0.0609)\end{array}$ & $\begin{array}{c}0.0570 \\
(0.0575)\end{array}$ \\
\hline Female*Age at CR & $\begin{array}{c}1.050 \\
(0.160)\end{array}$ & $\begin{array}{l}0.0491 \\
(0.153)\end{array}$ \\
\hline Ph.D. from a Paris university ${ }^{a}$ & $\begin{array}{l}1.928^{*} \\
(0.708)\end{array}$ & $\begin{array}{l}0.656^{*} \\
(0.367)\end{array}$ \\
\hline Female*Ph.D. from a Paris university & $\begin{array}{c}0.222 \\
(0.220)\end{array}$ & $\begin{array}{l}-1.504 \\
(0.991)\end{array}$ \\
\hline Ph.D. from a French university ${ }^{a}$ & $\begin{array}{l}1.040 \\
(0.357)\end{array}$ & $\begin{array}{l}0.0394 \\
(0.344)\end{array}$ \\
\hline Female*Ph.D. from a French university & $\begin{array}{c}0.449 \\
(0.327)\end{array}$ & $\begin{array}{l}-0.801 \\
(0.728)\end{array}$ \\
\hline Ph.D. graduation year $>=1991^{\mathrm{b}}$ & $\begin{array}{c}0.984 \\
(0.405)\end{array}$ & $\begin{array}{l}-0.0163 \\
(0.411)\end{array}$ \\
\hline Female $*$ Ph.D. graduation year $>=1991$ & $\begin{array}{c}16.48^{* * *} \\
(16.53)\end{array}$ & $\begin{array}{c}2.802^{* * *} \\
(1.003)\end{array}$ \\
\hline Recruited as CR1 & $\begin{array}{c}0.858 \\
(0.226)\end{array}$ & $\begin{array}{c}-0.153 \\
(0.263)\end{array}$ \\
\hline Female*Recruited as CR1 & $\begin{array}{l}1.346 \\
(1.259)\end{array}$ & $\begin{array}{c}0.297 \\
(0.935)\end{array}$ \\
\hline Gender parity initiative (MPPF) & $\begin{array}{c}0.462 \\
(0.520)\end{array}$ & $\begin{array}{c}-0.772 \\
(1.125)\end{array}$ \\
\hline Female ${ }^{*}$ Gender parity initiative (MPPF) & $\begin{array}{c}0.548 \\
(1.193)\end{array}$ & $\begin{array}{l}-0.602 \\
(2.179)\end{array}$ \\
\hline Section dummies & Yes & Yes \\
\hline Section dummies interacted with Female & Yes & 0.099 \\
\hline
\end{tabular}




\begin{tabular}{lcc} 
Pseudo R squared & 0.099 & 276 \\
Number of scientists & 276 & 166 \\
Number of scientists not promoted (censored) & 166 & 2,531 \\
Observations & 2,531 & 0.096 \\
\hline
\end{tabular}

Note: In Column 1, a coefficient lower than one is associated with a reduction of the hazard rate of promotion, while a coefficient greater than one is associated with an increase of the hazard rate of promotion. Column 2 reports the raw coefficients useful to

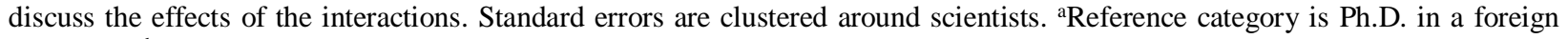
university; 'be redefined the Ph.D. cohort dummies as follows: Ph.D. graduation year $>=1991$ and Ph.D. graduation year < 1991. 


\section{Appendix B3}

In this appendix, we address the concern that scientists experience alternative 'exit modes' other than promotion, such us leaving INP for other job opportunities, or retire. In-depth discussions with scientists working at CNRS suggest that the rate of abandon of CNRS for external job opportunities is very low, which is confirmed by internal CNRS statistics on researcher mobility. ${ }^{17}$ However, we have selected a sub-sample of scientists born between 1960 and 1969 in order to have a cohort of individuals who are not at risk of retirement and whose only possible 'expected exit' is promotion. ${ }^{18}$ Table B3-1 and B3-2 show that, although the sample reduces to 153 scientists (32 females and 121 males), the results are qualitatively the same as those reported in Tables 3 and 4.

\footnotetext{
${ }^{17}$ See data about personal mobility at http://bilansocial.dsi.cnrs.fr/pdf/BSP-2015.pdf

${ }^{18}$ In this subsample, the oldest scientist is an individual born in 1960 and who was 58 in 2017. In France, the age of 58 is largely below than the age of retirement.
} 
Table B3-1: Event history analysis for promotion to DR using Cox’s partial likelihood estimator for the proportional hazard model. The study sample includes only 153 scientists born between 1960 and 1969.

\begin{tabular}{|c|c|c|c|c|}
\hline & $\begin{array}{c}\text { (1) } \\
\text { All } \\
\text { Hazard ratio }\end{array}$ & $\begin{array}{c}(2) \\
\text { All } \\
\text { Hazard ratio } \\
\end{array}$ & $\begin{array}{c}\text { (3) } \\
\text { All } \\
\text { Hazard ratio }\end{array}$ & $\begin{array}{c}\text { (4) } \\
\text { All } \\
\text { Hazard ratio } \\
\end{array}$ \\
\hline Female & $\begin{array}{c}0.565 * * \\
(0.128)\end{array}$ & $\begin{array}{l}0.661^{*} \\
(0.163)\end{array}$ & $\begin{array}{c}0.873 \\
(0.223)\end{array}$ & $\begin{array}{c}1.013 \\
(0.268)\end{array}$ \\
\hline Cumulated number of articles in $\mathrm{t}-1$ & & & $\begin{array}{l}1.020^{* * *} \\
(0.00475)\end{array}$ & $\begin{array}{l}1.046 * * * \\
(0.00986)\end{array}$ \\
\hline Cumulated number of conference papers in $\mathrm{t}-1$ & & & $\begin{array}{c}1.009 \\
(0.00609)\end{array}$ & $\begin{array}{c}0.999 \\
(0.0105)\end{array}$ \\
\hline Average number of citations in $\mathrm{t}-1$ & & & $\begin{array}{l}1.200 * * \\
(0.0964)\end{array}$ & $\begin{array}{l}1.246 * * * \\
(0.0826)\end{array}$ \\
\hline At least one EPO patent in $\mathrm{t}-1$ & & & & $\begin{array}{c}0.618 \\
(0.282)\end{array}$ \\
\hline Cumulated number of collaborators in $\mathrm{t}-1$ & & & & $\begin{array}{l}0.986^{* *} \\
(0.00577)\end{array}$ \\
\hline Cumulated number Ph.D. theses supervised in t-1 & & & & $\begin{array}{c}1.496 * * * \\
(0.210)\end{array}$ \\
\hline Cumulated years as head of a research team in t-1 & & & & $\begin{array}{c}1.017 \\
(0.0332)\end{array}$ \\
\hline $\begin{array}{l}\text { Cumulated years with other research } \\
\text { responsibilities in t-1 }\end{array}$ & & & & $\begin{array}{c}1.063^{*} \\
(0.0365)\end{array}$ \\
\hline Family size in $\mathrm{t}-1$ & & $\begin{array}{c}1.029 \\
(0.0771)\end{array}$ & & $\begin{array}{c}0.974 \\
(0.0883)\end{array}$ \\
\hline One child less than 3 years old & & $\begin{array}{c}0.718 \\
(0.191)\end{array}$ & & $\begin{array}{c}0.696 \\
(0.187)\end{array}$ \\
\hline Age at CR & & $\begin{array}{c}1.110^{*} \\
(0.0594)\end{array}$ & & $\begin{array}{l}1.121^{* * *} \\
(0.0480)\end{array}$ \\
\hline Ph.D. from a Paris university ${ }^{a}$ & & $\begin{array}{c}1.471 \\
(0.489)\end{array}$ & & $\begin{array}{c}0.718 \\
(0.226)\end{array}$ \\
\hline Ph.D. from a French university ${ }^{\mathrm{a}}$ & & $\begin{array}{c}1.356 \\
(0.464)\end{array}$ & & $\begin{array}{c}0.557 \\
(0.199)\end{array}$ \\
\hline Ph.D. graduation year $>=1991^{\mathrm{b}}$ & & $\begin{array}{c}0.764 \\
(0.175)\end{array}$ & & $\begin{array}{c}0.586^{* *} \\
(0.131)\end{array}$ \\
\hline Recruited as CR1 & & $\begin{array}{c}1.690 \\
(0.665)\end{array}$ & & $\begin{array}{c}1.593 \\
(0.534)\end{array}$ \\
\hline Section dummies & No & Yes & No & Yes \\
\hline Pseudo R squared & 0.006 & 0.029 & 0.044 & 0.104 \\
\hline Number of scientists & 153 & 153 & 153 & 153 \\
\hline Number of scientists not promoted (censored) & 38 & 38 & 38 & 38 \\
\hline Observations & 2,628 & 2,628 & 2,628 & 2,628 \\
\hline
\end{tabular}

Note: A coefficient lower than one is associated with a reduction of the hazard rate of promotion, while a coefficient greater than one is associated with an increase of the hazard rate of promotion. Standard errors are clustered around scientists. ${ }^{\text {aReference }}$

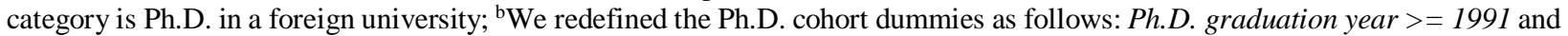
Ph.D. graduation year < 1991. Due to the limited number of observations, we dropped the variable Gender parity initiative (MPPF) and At least one ANR or EU grant in t-1 to obtain convergent pseudo-likelihood estimations. 
Table B3-2: Event history analysis using Cox’s partial likelihood estimator for the proportional hazard model. Promotion from DR2 to DR1. The model includes interactions with the Female variable.

\begin{tabular}{|c|c|c|}
\hline & $\begin{array}{c}(1) \\
\text { Hazard ratio }\end{array}$ & $\begin{array}{c}(2) \\
\text { Raw coefficients }\end{array}$ \\
\hline Female & $\begin{array}{c}7.815 \\
(28.74)\end{array}$ & $\begin{array}{c}2.056 \\
(3.677)\end{array}$ \\
\hline Cumulated number of articles in t-1 & $\begin{array}{l}1.055^{* * *} \\
(0.0108)\end{array}$ & $\begin{array}{c}0.0537 * * * \\
(0.0102)\end{array}$ \\
\hline Female*Cumulated number of articles in $t-1$ & $\begin{array}{c}0.985 \\
(0.0330)\end{array}$ & $\begin{array}{l}-0.0154 \\
(0.0335)\end{array}$ \\
\hline Cumulated number of conference papers in $\mathrm{t}-1$ & $\begin{array}{c}0.998 \\
(0.0107)\end{array}$ & $\begin{array}{l}-0.00185 \\
(0.0107)\end{array}$ \\
\hline Female ${ }^{*}$ Cumulated number of conference papers in $t-1$ & $\begin{array}{l}1.050 \\
(0.101)\end{array}$ & $\begin{array}{c}0.0486 \\
(0.0959)\end{array}$ \\
\hline Average number of citations in $\mathrm{t}-1$ & $\begin{array}{c}1.299 * * * \\
(0.118)\end{array}$ & $\begin{array}{l}0.262 * * * \\
(0.0910)\end{array}$ \\
\hline Female $*$ Average number of citations in $t-1$ & $\begin{array}{c}0.976 \\
(0.228)\end{array}$ & $\begin{array}{l}-0.0248 \\
(0.234)\end{array}$ \\
\hline At least one EPO patent in $\mathrm{t}-1$ & $\begin{array}{c}0.810 \\
(0.365)\end{array}$ & $\begin{array}{c}-0.211 \\
(0.451)\end{array}$ \\
\hline Female $*$ At least one EPO patent in $t-1$ & $\begin{array}{c}0.865 \\
(1.258)\end{array}$ & $\begin{array}{c}-0.145 \\
(1.454)\end{array}$ \\
\hline Cumulated number of collaborators in $\mathrm{t}-1$ & $\begin{array}{l}0.980 * * * \\
(0.00603)\end{array}$ & $\begin{array}{c}-0.0205^{* * * *} \\
(0.00616)\end{array}$ \\
\hline Female ${ }^{*}$ Cumulated number of collaborators in $t-1$ & $\begin{array}{c}1.007 \\
(0.0323)\end{array}$ & $\begin{array}{l}0.00734 \\
(0.0321)\end{array}$ \\
\hline Cumulated number Ph.D. theses supervised in $\mathrm{t}-1$ & $\begin{array}{c}1.702 * * * \\
(0.254)\end{array}$ & $\begin{array}{c}0.532 * * * \\
(0.150)\end{array}$ \\
\hline Female*Cumulated number Ph.D. theses supervised in $t-1$ & $\begin{array}{c}0.802 \\
(0.306)\end{array}$ & $\begin{array}{l}-0.220 \\
(0.381)\end{array}$ \\
\hline Cumulated years as head of a research team in t-1 & $\begin{array}{c}0.960 \\
(0.0353)\end{array}$ & $\begin{array}{l}-0.0411 \\
(0.0368)\end{array}$ \\
\hline Female ${ }^{*}$ Cumulated years as head of a research team in $t-1$ & $\begin{array}{l}1.306^{* *} \\
(0.144)\end{array}$ & $\begin{array}{c}0.267^{* *} \\
(0.111)\end{array}$ \\
\hline Cumulated years with other research responsibilities in t-1 & $\begin{array}{l}1.111^{* * *} \\
(0.0398)\end{array}$ & $\begin{array}{l}0.105 * * * \\
(0.0358)\end{array}$ \\
\hline Female*Cumulated years with other research responsibilities in $t-1$ & $\begin{array}{c}0.809 \\
(0.182)\end{array}$ & $\begin{array}{c}-0.212 \\
(0.225)\end{array}$ \\
\hline Family size in $\mathrm{t}-1$ & $\begin{array}{c}1.063 \\
(0.102)\end{array}$ & $\begin{array}{c}0.0609 \\
(0.0963)\end{array}$ \\
\hline Female $*$ Family size in $t-1$ & $\begin{array}{c}1.067 \\
(0.433)\end{array}$ & $\begin{array}{l}0.0649 \\
(0.406)\end{array}$ \\
\hline One child less than 3 years old & $\begin{array}{c}0.711 \\
(0.195)\end{array}$ & $\begin{array}{c}-0.341 \\
(0.275)\end{array}$ \\
\hline Female* One child less than 3 years old & $\begin{array}{c}0.546 \\
(0.435)\end{array}$ & $\begin{array}{l}-0.605 \\
(0.797)\end{array}$ \\
\hline Age at CR & $\begin{array}{c}1.106^{*} \\
(0.0612)\end{array}$ & $\begin{array}{c}0.101^{*} \\
(0.0553)\end{array}$ \\
\hline Female*Age at $C R$ & $\begin{array}{c}0.892 \\
(0.0963)\end{array}$ & $\begin{array}{l}-0.114 \\
(0.108)\end{array}$ \\
\hline Ph.D. from a Paris university ${ }^{a}$ & $\begin{array}{l}0.478^{*} \\
(0.193)\end{array}$ & $\begin{array}{l}-0.738^{*} \\
(0.404)\end{array}$ \\
\hline Female*Ph.D. from a Paris university & $\begin{array}{c}1.210 \\
(1.474)\end{array}$ & $\begin{array}{c}0.191 \\
(1.218)\end{array}$ \\
\hline Ph.D. from a French university ${ }^{a}$ & $\begin{array}{l}0.319 * * \\
(0.153)\end{array}$ & $\begin{array}{c}-1.144^{* *} \\
(0.481)\end{array}$ \\
\hline Female*Ph.D. from a French university & $\begin{array}{l}4.403^{*} \\
(3.647)\end{array}$ & $\begin{array}{l}1.482 * \\
(0.828)\end{array}$ \\
\hline Ph.D. graduation year $>=1991^{\mathrm{b}}$ & $\begin{array}{c}0.543^{* *} \\
(0.134)\end{array}$ & $\begin{array}{c}-0.610^{* *} \\
(0.247)\end{array}$ \\
\hline Female $*$ Ph.D. graduation year $>=1991$ & $\begin{array}{c}1.331 \\
(1.280)\end{array}$ & $\begin{array}{c}0.286 \\
(0.962)\end{array}$ \\
\hline Recruited as CR1 & $\begin{array}{c}1.525 \\
(0.550)\end{array}$ & $\begin{array}{c}0.422 \\
(0.360)\end{array}$ \\
\hline Female*Recruited as CR1 & $\begin{array}{l}4.466^{*} \\
(4.053)\end{array}$ & $\begin{array}{l}1.496^{*} \\
(0.908)\end{array}$ \\
\hline Section dummies & Yes & Yes \\
\hline Section dummies interacted with Female & Yes & Yes \\
\hline Pseudo R squared & 0.131 & 0.131 \\
\hline $\begin{array}{l}\text { Number of scientists } \\
\text { Number of scientists not promoted (censored) }\end{array}$ & $\begin{array}{c}153 \\
38\end{array}$ & $\begin{array}{c}153 \\
38\end{array}$ \\
\hline Observations & 2,628 & 2,628 \\
\hline
\end{tabular}

Note: In Column 1, a coefficient lower than one is associated with a reduction of the hazard rate of promotion, while a coefficient greater than one is associated with an increase of the hazard rate of promotion. Column 2 reports the raw coefficients useful to discuss the effects of the interactions. Standard errors are clustered around scientists. ${ }^{2}$ Reference category is Ph.D. in a foreign 
university; ${ }^{b}$ We redefined the Ph.D. cohort dummies as follows: Ph.D. graduation year $>=1991$ and Ph.D. graduation year $<$ 1991. Due to the limited number of observations, we dropped the variable Gender parity initiative (MPPF) and At least one ANR or EU grant in $t-1$ to obtain convergent pseudo-likelihood estimations. 


\section{Appendix B4}

This appendix reports the event history analysis for promotion to DR using maximum likelihood estimation of a parametric model including unshared frailty. The unshared frailty $\alpha$ represents the unobservable model heterogeneity (Equation B4-1). Specifically, $\alpha$ is a gammadistributed random variable with average $1 / \Theta$ and variance $\Theta$, i.e., $\operatorname{Gamma}(1 / \Theta, \Theta)$.

$$
h_{i}(t)=\alpha_{i} h_{0}(t) e^{\left(\beta_{1} x_{1, i}+\beta_{2} x_{2, i}(t-1)\right)} \quad \text { Equation B4-1 }
$$

We assume that our baseline hazard function has a Weibull distribution $h_{0}(t)=p t^{p-1}$. We end up with Equation B4-2 that writes as follow:

$$
h_{i}(t)=\alpha_{i} h_{0}(t) e^{\left(\beta_{1} x_{1, i}+\beta_{2} x_{2, i}(t-1)\right)}=\alpha_{i} p t^{p-1} e^{\left(\beta_{1} x_{1, i}+\beta_{2} x_{2, i}(t-1)\right)} \quad \text { Equation B4-2 }
$$

The results of estimation reported in Tables B4-1 and B4-2 are consistent with those reported in Tables 3 and 4, except for the variable Family size in $t-1$ that loses its significance for male researchers in Table B4-2. 
Table B4-1: Event history analysis for promotion to DR using maximum likelihood estimations of the parametric model assuming the Weibull functional form of the baseline hazard $\left(h_{0}(t)=\right.$ $\left.p t^{p-1}\right)$ and unshared frailty with a gamma distribution gamma $(1 / \Theta, \Theta)$.

\begin{tabular}{|c|c|c|c|c|}
\hline & $\begin{array}{c}\text { (1) } \\
\text { All } \\
\text { Hazard ratio }\end{array}$ & $\begin{array}{c}(2) \\
\text { All } \\
\text { Hazard ratio }\end{array}$ & $\begin{array}{c}\text { (3) } \\
\text { All } \\
\text { Hazard ratio }\end{array}$ & $\begin{array}{c}\text { (4) } \\
\text { All } \\
\text { Hazard ratio }\end{array}$ \\
\hline Female & $\begin{array}{c}0.449 * * * \\
(0.111)\end{array}$ & $\begin{array}{c}0.444 * * * \\
(0.112)\end{array}$ & $\begin{array}{c}0.715 \\
(0.167)\end{array}$ & $\begin{array}{c}0.952 \\
(0.297)\end{array}$ \\
\hline Cumulated number of articles in $\mathrm{t}-1$ & & & $\begin{array}{l}1.035^{* * * *} \\
(0.00678)\end{array}$ & $\begin{array}{l}1.065^{* * * *} \\
(0.0140)\end{array}$ \\
\hline Cumulated number of conference papers in t-1 & & & $\begin{array}{c}0.985 \\
(0.00982)\end{array}$ & $\begin{array}{c}0.994 \\
(0.0147)\end{array}$ \\
\hline Average number of citations in $\mathrm{t}-1$ & & & $\begin{array}{c}1.040 \\
(0.0663)\end{array}$ & $\begin{array}{c}1.118 \\
(0.118)\end{array}$ \\
\hline At least one EPO patent in $\mathrm{t}-1$ & & & & $\begin{array}{c}1.383 \\
(0.818)\end{array}$ \\
\hline Cumulated number of collaborators in $\mathrm{t}-1$ & & & & $\begin{array}{c}0.972 * * * \\
(0.0106)\end{array}$ \\
\hline Cumulated number Ph.D. theses supervised in t-1 & & & & $\begin{array}{c}3.056 * * * \\
(1.002)\end{array}$ \\
\hline Cumulated years as head of a research team in t-1 & & & & $\begin{array}{l}1.209^{* * * *} \\
(0.0829)\end{array}$ \\
\hline Cumulated years with other research responsibilities in t-1 & & & & $\begin{array}{c}1.043 \\
(0.0802)\end{array}$ \\
\hline At least one ANR or EU grant in $\mathrm{t}-1$ & & & & $\begin{array}{c}0.715 \\
(0.479)\end{array}$ \\
\hline Family size in $\mathrm{t}-1$ & & $\begin{array}{c}1.171 \\
(0.115)\end{array}$ & & $\begin{array}{c}1.188 \\
(0.149)\end{array}$ \\
\hline One child less than 3 years old & & $\begin{array}{c}0.660 \\
(0.167)\end{array}$ & & $\begin{array}{c}0.594 \\
(0.204)\end{array}$ \\
\hline Age at CR & & & & $\begin{array}{l}1.131^{*} \\
(0.0804)\end{array}$ \\
\hline Ph.D. from a Paris university & & & & $\begin{array}{c}0.926 \\
(0.360)\end{array}$ \\
\hline Ph.D. from a French university & & & & $\begin{array}{c}0.875 \\
(0.325)\end{array}$ \\
\hline Ph.D. graduation year 2001-2017 & & & & $\begin{array}{c}0.417 \\
(0.331)\end{array}$ \\
\hline Ph.D. graduation year $1991-2000$ & & & & $\begin{array}{c}0.631 \\
(0.266)\end{array}$ \\
\hline Recruited as CR1 & & & & $\begin{array}{c}7.792 * * * \\
(3.982)\end{array}$ \\
\hline Gender parity initiative (MPPF) & & $\begin{array}{c}0.975 \\
(0.224)\end{array}$ & & $\begin{array}{c}0.984 \\
(0.477)\end{array}$ \\
\hline Section dummies & No & Yes & No & Yes \\
\hline Constant & $\begin{array}{c}3.80 \mathrm{e}-06 * * * \\
(3.45 \mathrm{e}-06)\end{array}$ & $\begin{array}{c}5.61 \mathrm{e}-06 * * * \\
(5.15 \mathrm{e}-06)\end{array}$ & $\begin{array}{c}7.12 \mathrm{e}-06 * * * \\
(6.22 \mathrm{e}-06)\end{array}$ & $\begin{array}{c}8.84 \mathrm{e}-09 * * * \\
(2.88 \mathrm{e}-08)\end{array}$ \\
\hline Log-likelihood & -282.27 & -279.969 & -252.191 & -173.112 \\
\hline$\widehat{\theta}$ & 1.497 & 1.459 & 0.953 & 1.501 \\
\hline Likelihood ratio test of $\Theta=0$ (Pvalue) & 0.000 & 0.000 & 0.000 & 0.000 \\
\hline Weibull parameter $\hat{p}$ & 4.559 & 4.364 & 3.811 & 4.735 \\
\hline Number of scientists & 604 & 604 & 604 & 604 \\
\hline Number of scientists not promoted (censored) & 328 & 328 & 328 & 328 \\
\hline Observations & 7,805 & 7,805 & 7,805 & 7,805 \\
\hline
\end{tabular}

Note: A coefficient lower than one is associated with a reduction of the hazard rate of promotion, while a coefficient greater than

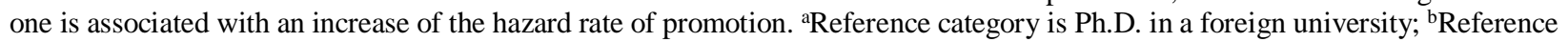
category is Ph.D. graduation year before 1991. 
Table B4-2: Event history analysis for promotion to DR using maximum likelihood estimations of the parametric model assuming the Weibull functional form of the baseline hazard $\left(h_{0}(t)=\right.$ $\left.p t^{p-1}\right)$ and unshared frailty with a gamma distribution gamma $(1 / \Theta, \Theta)$. The model is estimated including interactions with the Female variable.

\begin{tabular}{|c|c|c|}
\hline & $\begin{array}{c}\text { (1) } \\
\text { Hazard ratio }\end{array}$ & $\begin{array}{c}(2) \\
\text { Raw coefficients }\end{array}$ \\
\hline Female & $\begin{array}{c}0.547 \\
(2.868)\end{array}$ & $\begin{array}{l}-0.604 \\
(5.247)\end{array}$ \\
\hline Cumulated number of articles in $\mathrm{t}-1$ & $\begin{array}{l}1.068 * * * \\
(0.0146)\end{array}$ & $\begin{array}{c}0.0654 * * * \\
(0.0137)\end{array}$ \\
\hline Female ${ }^{*}$ Cumulated number of articles in $t-1$ & $\begin{array}{c}0.992 \\
(0.0554)\end{array}$ & $\begin{array}{l}-0.00775 \\
(0.0559)\end{array}$ \\
\hline Cumulated number of conference papers in t- 1 & $\begin{array}{c}1.002 \\
(0.0166)\end{array}$ & $\begin{array}{l}0.00208 \\
(0.0166)\end{array}$ \\
\hline Female ${ }^{*}$ Cumulated number of conference papers in $t-1$ & $\begin{array}{c}0.926 \\
(0.0893)\end{array}$ & $\begin{array}{l}-0.0771 \\
(0.0965)\end{array}$ \\
\hline Average number of citations in $\mathrm{t}-1$ & $\begin{array}{l}1.089 \\
(0.122)\end{array}$ & $\begin{array}{l}0.0850 \\
(0.112)\end{array}$ \\
\hline Female*Average number of citations in $t-1$ & $\begin{array}{l}1.170 \\
(0.645)\end{array}$ & $\begin{array}{c}0.157 \\
(0.551)\end{array}$ \\
\hline At least one EPO patent in $\mathrm{t}-1$ & $\begin{array}{c}1.267 \\
(0.849)\end{array}$ & $\begin{array}{c}0.237 \\
(0.670)\end{array}$ \\
\hline Female*At least one EPO patent in $t-1$ & $\begin{array}{c}0.562 \\
(1.383)\end{array}$ & $\begin{array}{l}-0.577 \\
(2.462)\end{array}$ \\
\hline Cumulated number of collaborators in $\mathrm{t}-1$ & $\begin{array}{c}0.968 * * * \\
(0.0118)\end{array}$ & $\begin{array}{c}-0.0321 * * * \\
(0.0121)\end{array}$ \\
\hline Female ${ }^{*}$ Cumulated number of collaborators in $t-1$ & $\begin{array}{c}1.018 \\
(0.0438)\end{array}$ & $\begin{array}{c}0.0175 \\
(0.0430)\end{array}$ \\
\hline Cumulated number Ph.D. theses supervised in t-1 & $\begin{array}{c}3.250 * * * \\
(1.246)\end{array}$ & $\begin{array}{c}1.179 * * * \\
(0.383)\end{array}$ \\
\hline Female ${ }^{*}$ Cumulated number Ph.D. theses supervised in $t-1$ & $\begin{array}{c}1.451 \\
(1.651)\end{array}$ & $\begin{array}{c}0.372 \\
(1.138)\end{array}$ \\
\hline Cumulated years as head of a research team in $\mathrm{t}-1$ & $\begin{array}{l}1.191^{* *} \\
(0.0897)\end{array}$ & $\begin{array}{l}0.175^{* *} \\
(0.0753)\end{array}$ \\
\hline Female ${ }^{*}$ Cumulated years as head of a research team in $t-1$ & $\begin{array}{c}1.057 \\
(0.267)\end{array}$ & $\begin{array}{l}0.0553 \\
(0.252)\end{array}$ \\
\hline Cumulated years with other research responsibilities in t-1 & $\begin{array}{c}1.002 \\
(0.0844)\end{array}$ & $\begin{array}{l}0.00163 \\
(0.0843)\end{array}$ \\
\hline Female $*$ Cumulated years with other research responsibilities in $t-1$ & $\begin{array}{l}1.306 \\
(0.403)\end{array}$ & $\begin{array}{c}0.267 \\
(0.308)\end{array}$ \\
\hline At least one ANR or EU grant in t-1 & $\begin{array}{c}0.325 \\
(0.286)\end{array}$ & $\begin{array}{l}-1.123 \\
(0.879)\end{array}$ \\
\hline Female*At least one ANR or EU grant in $t-1$ & $\begin{array}{l}17.95^{*} \\
(28.74)\end{array}$ & $\begin{array}{l}2.888^{*} \\
(1.601)\end{array}$ \\
\hline Family size in $\mathrm{t}-1$ & $\begin{array}{l}1.216 \\
(0.190)\end{array}$ & $\begin{array}{c}0.196 \\
(0.156)\end{array}$ \\
\hline Female $*$ Family size in $t-1$ & $\begin{array}{l}1.141 \\
(0.436)\end{array}$ & $\begin{array}{c}0.132 \\
(0.382)\end{array}$ \\
\hline One child less than 3 years old & $\begin{array}{c}0.581 \\
(0.221)\end{array}$ & $\begin{array}{c}-0.542 \\
(0.380)\end{array}$ \\
\hline Female* One child less than 3 years old & $\begin{array}{c}1.132 \\
(1.716)\end{array}$ & $\begin{array}{c}0.124 \\
(1.517)\end{array}$ \\
\hline Age at CR & $\begin{array}{c}1.118 \\
(0.0925)\end{array}$ & $\begin{array}{c}0.112 \\
(0.0828)\end{array}$ \\
\hline Female*Age at $C R$ & $\begin{array}{c}0.973 \\
(0.182)\end{array}$ & $\begin{array}{l}-0.0275 \\
(0.187)\end{array}$ \\
\hline Ph.D. from a Paris university & $\begin{array}{l}1.163 \\
(0.525)\end{array}$ & $\begin{array}{c}0.151 \\
(0.452)\end{array}$ \\
\hline Female*Ph.D. from a Paris university & $\begin{array}{c}0.624 \\
(0.769)\end{array}$ & $\begin{array}{c}-0.471 \\
(1.233)\end{array}$ \\
\hline Ph.D. from a French university & $\begin{array}{l}1.043 \\
(0.440)\end{array}$ & $\begin{array}{l}0.0424 \\
(0.421)\end{array}$ \\
\hline Female*Ph.D. from a French university & $\begin{array}{c}0.355 \\
(0.412)\end{array}$ & $\begin{array}{l}-1.036 \\
(1.161)\end{array}$ \\
\hline Ph.D. graduation year 2001-2017 & $\begin{array}{c}0.341 \\
(0.323)\end{array}$ & $\begin{array}{l}-1.075 \\
(0.948)\end{array}$ \\
\hline
\end{tabular}


Female*Ph.D. graduation year 2001-2017

Ph.D. graduation year 1991-2000 = 1

Female*Ph.D. graduation year 1991-2000

Recruited as CR1

Female*Recruited as CR1

Gender parity initiative (MPPF)

Female*Gender parity initiative (MPPF)

Section dummies

Section dummies interacted with Female

Constant

Log-likelihood

Likelihood ratio test of $\Theta=0$ (Pvalue)

Weibull parameter $\hat{p}$

Number of scientists

Number of scientists not promoted (censored)

Observations

Note: In Column 1, a coefficient lower than one is associated with a reduction of the hazard rate of promotion, while a coefficient greater than one is associated with an increase of the hazard rate of promotion. Column 2 reports the raw coefficients useful to discuss the effects of the interactions.

$\begin{array}{cc}6.355 & 1.849 \\ (18.49) & (2.910) \\ 0.557 & -0.586 \\ (0.285) & (0.513) \\ 1.946 & 0.666 \\ (2.439) & (1.253) \\ 9.975 * * * & 2.300 * * * \\ (6.105) & (0.612) \\ 0.685 & -0.379 \\ (0.930) & (1.359) \\ 0.963 & -0.0380 \\ (0.552) & (0.573) \\ 0.852 & -0.160 \\ (1.288) & (1.512) \\ \text { Yes } & \text { Yes } \\ \text { Yes } & \text { Yes } \\ 9.31 \mathrm{e}-09 * * * & -18.49 * * * \\ (3.36 \mathrm{e}-08) & (3.613) \\ -163.871 & -163.871 \\ 1.512 & 1.512 \\ 0.000 & 0.000 \\ 4.889 & 4.889 \\ 604 & 604 \\ 328 & 328 \\ 7,805 & 7,805\end{array}$

